\title{
North American Specialty Cut Flower Production and Postharvest Survey
}

\author{
Cristian E. Loyola, John M. Dole ${ }^{1}$, and Rebecca Dunning
}

\begin{abstract}
AdDITIONAL INDEX WORDs. botrytis, hydration, pests, temperature, timing, zinnia
Summary. In the United States and Canada, there has been an increase in the demand for local specialty cut flowers and a corresponding increase in production. To assess the needs of the industry, we electronically surveyed 1098 cut flower producers and handlers in the United States and Canada regarding their current cut flower production and postharvest problems, and customer issues. We received a total of 210 responses, resulting in a $19 \%$ response rate. The results showed that the main production problem was insect management; crop timing was the second most important problem and disease management was the third. Crop timing encompasses a range of related issues such as determining the correct harvest stage, harvest windows that are too short, flowering all at once, or lack of control when the crop is ready to harvest. The main postharvest problems were temperature management, hydration, and flower food management. Timing and stem length were the two most mentioned species-specific production issues, with each one listed by $10 \%$ or more of the respondents for eight of the total 31 species. Regarding onfarm postharvest handling, hydration and vase life were the two most mentioned issues; they were reported for five and three species, respectively. For postharvest during storage and transport, damage and hydration were the most common issues; these were listed for three species each. The most commonly mentioned customer complaints were vase life and shattering, which were reported for six and two species, respectively. These results will allow researchers and businesses to focus on the major cut flower production and postharvest issues and on crops that are most in need of improvement in North America.
\end{abstract}

$\mathrm{C}$ flower production in the United States and Canada has resurged in recent years. A survey conducted by Granitz (2014) found that $67 \%$ of the cut flower producers in North Carolina experienced an increase in demand for cut flowers, especially locally produced flowers (Armitage and Laushman, 2003). The number of members of the Association of Specialty Cut Flower Growers (ASCFG) has increased from 500 during 1996 to 2014 to more than 1700 in 2018 (J. Laushman, personal communication). These new businesses are focusing on the production and use of specialty cut flowers instead of species grown off-shore, such as

Received for publication 7 Jan. 2019. Accepted for publication 1 Apr. 2019.

Published online 9 May 2019.

Department of Horticultural Science, North Carolina State University, 2721 Founders Drive, Raleigh, NC 27695-7609

This paper is part of a thesis submitted by Cristian E. Loyola to fulfill a Masters of Horticultural Science degree requirement.

${ }^{1}$ Corresponding author. E-mail: jmdole@ncsu.edu.

This is an open access article distributed under the CC BY-NC-ND license (https://creativecommons.org/ licenses/by-nc-nd/4.0/).

https://doi.org/10.21273/HORTTECH04270-19 roses (Table 1), carnations, alstroemeria, and chrysanthemums, that are shipped to the United States and Canada. Hundreds of species can be grown commercially as cut flowers in the southeast United States (Dole et al., 2017b). In North Carolina alone, more than 75 different species of cut flowers are grown (Granitz, 2014).

Due to the recent resurgence, more information is needed regarding current production and postharvest issues. The objectives of this work were to determine the major production and postharvest challenges facing the cut flower industry and the specific production and postharvest issues of 31 major crop species. This work will provide a guide for industry and academic researchers regarding the most important issues to be addressed for specialty cut flowers.

\section{Materials and methods}

The questionnaire was constructed and delivered using online software
(Survey Monkey, San Mateo, CA); they were emailed to 1098 members (each business received only one survey request) of the ASCFG. The survey asked questions regarding the business location, approximate size (based on number of full-time employees) and type of business, crops produced and/or handled, and production and postharvest problems across all crops and specifically for each of 31 crop species that were selected based on research in North Carolina, with the addition of species commonly grown in other parts of the United States and Canada (Bogash et al., 2012; Granitz, 2014). Data were collected from Apr. 2017 to June 2017, and recipients were reminded twice to complete the survey.

Respondents were provided with lists of 11 industry-wide production issues and 8 postharvest issues, and they were asked to select their top 5 issues and rank them from 1 to 5 , with the first ranked representing the most important problem (most severe) and the fifth ranked representing the least important problem for their business. Each number from 1 to 5 was allowed to be used only once for each respondent.

We also asked the respondents about their specific production and postharvest challenges and customer complaints for the 31 individual crop species. The species-specific postharvest problems were further divided into postharvest problems at the farm and postharvest problems during storage and transportation.

The production problems, postharvest problems, and customer complaints were represented as a percentage of the number of respondents who answered each question. If $10 \%$ or more of the respondents indicated that an issue was considered a problem for them, then it was included here. The exception was for production issues; because they were so numerous, we discussed only those problems that were mentioned for more than one species.

\section{Results and discussion}

We received a total of 210 responses, resulting in a $19 \%$ response rate. Two hundred of the respondents

\begin{tabular}{llll}
\hline $\begin{array}{l}\text { Units } \\
\text { To convert U.S. to SI, } \\
\text { multiply by }\end{array}$ & U.S. unit & SI unit & $\begin{array}{l}\text { To convert SI to U.S., } \\
\text { multiply by }\end{array}$ \\
\hline$\left({ }^{\circ} \mathrm{F}-32\right) \div 1.8$ & ${ }^{\circ} \mathrm{F}$ & ${ }^{\circ} \mathrm{C}$ & $\left({ }^{\circ} \mathrm{C} \times 1.8\right)+32$
\end{tabular}


Table 1. Taxonomic classifications of organisms of North American specialty cut flower production and postharvest issues (see also Table 4 for additional species).

\begin{tabular}{|c|c|}
\hline Common name & Taxonomic nomenclature \\
\hline \multicolumn{2}{|l|}{ Birds } \\
\hline Canada goose & Branta canadensis \\
\hline \multicolumn{2}{|l|}{ Diseases } \\
\hline Aster yellows & Candidatus Phytoplasma asteris \\
\hline Bacterial soft rot & Pectobacterium carotovora \\
\hline Black spot & Diplocarpon rosae \\
\hline Botrytis & Botrytis cinerea \\
\hline Downy mildew & Peronosporaceae \\
\hline Fusarium & Fusarium oxysporum \\
\hline \multicolumn{2}{|c|}{ Mildew (see downy mildew and powdery mildew) } \\
\hline Root/crown rot & Phytophthora species \\
\hline Powdery mildew & Erysiphales \\
\hline Rust & Pucciniales \\
\hline \multicolumn{2}{|l|}{ Insects and related organisms } \\
\hline Aphid & Aphidoidea \\
\hline Armyworm & Spodoptera frugiperda \\
\hline Blister beetle & Meloidae \\
\hline Corn root worm & Diabrotica species \\
\hline \multirow[t]{4}{*}{ Cucumber beetle } & Acalymma vittatum \\
\hline & A. trivittatum \\
\hline & Diabrotia undecimpunctata \\
\hline & D. balteata \\
\hline Earwig & Dermaptera \\
\hline Flea beetle & Chrysomelidae \\
\hline Grasshopper & Caelifera \\
\hline Japanese beetle & Popillia japonica \\
\hline Leafcutting bee & Megachilidae \\
\hline Lily beetle & Lilioceris lilii \\
\hline Lygus bug & Lygus species \\
\hline Mealybug & Pseudococcidae \\
\hline \multirow[t]{2}{*}{ Predatory mites } & Amblyseius montdorensis \\
\hline & Neoseiulus cucumeris \\
\hline Shield bug & Pentatomoidae \\
\hline Slugs/snails & Stylommatophora \\
\hline Southern root-knot nematode & Melodogyne incognita \\
\hline Spider mite & Tetranychus species \\
\hline Spittle bug & Cercopoidea \\
\hline \multirow[t]{2}{*}{ Stem borer } & Ostrinia nubilalis \\
\hline & Papaipema nebris \\
\hline Symphylan & Scutigerella immaculata \\
\hline Tarnished plant bug & Lygus lineolaris \\
\hline Thrips & Thysanoptera \\
\hline Western flower thrip & Frankliniella occidentallis \\
\hline Whitefly & Aleyrodidnae \\
\hline \multicolumn{2}{|l|}{ Mammals } \\
\hline Cat & Felis catus \\
\hline Chipmunk & Marmotini species \\
\hline Deer & Odocoileus species \\
\hline Gopher & Geomyidae \\
\hline Mouse & Mus species \\
\hline Rabbit & Sylvilagus species \\
\hline Rat & Rattus species \\
\hline Rodent & Rodentia \\
\hline \multirow[t]{2}{*}{ Squirrel } & Sciurus species \\
\hline & Tamiasciurus species \\
\hline Vole & Microtus species \\
\hline Woodchuck & Marmota monax \\
\hline
\end{tabular}

(Continued on next page) had small businesses with no more than 9 employees (95\%), 4 respondents had between 10 and 19 employees $(2 \%), 4$ respondents had between 20 and 49 employees (2\%), and only 2 respondents had between 100 and 200 employees (1\%). Because most of the respondents were small businesses, 149 of the respondents were the owners, 32 were growers, and the rest (29 respondents) had some other position or combination of positions (Table 2 ).

One hundred ninety-four of the respondents were located in the United States (93\%) and 15 (7\%) were in Canada (Fig. 1). The respondents were grouped according to their climate regions in the United States as determined by the National Center for Environmental Information (Karl and Koss, 1984). Based on these regions, $55 \%$ of the respondents were located in the northeast $(29 \%)$, central $(13 \%)$, and southeast (13\%) regions of the United States, and the remainder were in the south $(8 \%)$, Alaska (8\%), upper midwest (7\%), northwest $(7 \%)$, west $(4 \%)$, southwest $(3 \%)$, and west north-central (1\%) regions.

The five most common grown or handled crops were zinnia, peony, snapdragon, sunflower, and dahlia (Table 3). Three of the five species, zinnia, sunflower, and snapdragon, were also among the top five species reported by Granitz (2014) in her survey of the North Carolina specialty cut flower producers. The remaining two species, cockscomb and lily, in the Granitz (2014) survey were listed as number 7 and 22, respectively, in the current survey. Approximately 30\% of respondents produced or handled 13 to 18 different crops (Fig. 2), $\approx 33 \%$ produced 1 to 12 species, and $26 \%$ produced 19 or more species. Ten percent of the respondents did not specify which crops they handled.

In addition to the 31 most commonly grown cut flower species (Table $3)$, respondents reported growing another 99 cut flower species and categories (Table 4). Eucalyptus (11 respondents), black-eyed susan (8), and chrysanthemum $(8)$ were the most commonly reported genera. The least common major cut flower in the survey, dutch iris, was grown by 22 respondents; 11 respondents reported that they grow eucalyptus, indicating that the major cut flowers were 
Table 1. (Continued) Taxonomic classifications of organisms of North American specialty cut flower production and postharvest issues (see also Table 4 for additional species).

\begin{tabular}{|c|c|}
\hline Common name & Taxonomic nomenclature \\
\hline \multicolumn{2}{|l|}{ Plants } \\
\hline Alstroemeria & Alstroemeria cultivars \\
\hline Ammi & Ammi cultivars \\
\hline Anemone & Anemone coronaria \\
\hline Blue flossflower & Ageratum houstonianum \\
\hline Calla & Zantedeschia cultivars \\
\hline Carnation & Dianthus caryophyllus \\
\hline Chrysanthemum & Chrysanthemum $\times$ grandiflorum \\
\hline Cockscomb & Celosia argentea crested group \\
\hline Cosmos & Cosmos pinnatus \\
\hline Dahlia & Dablia hybrids \\
\hline Delphinium & Delphinium hybrids \\
\hline Dutch iris & Iris $\times$ bollandica \\
\hline Garden rose & Rosa cultivars \\
\hline Gladiolus & Gladiolus hybrids \\
\hline Hydrangea & Hydrangea species \\
\hline Iris family & Iridaceae \\
\hline Larkspur & Consolida hybrids \\
\hline Lily & Lilium hybrids \\
\hline Lisianthus & Eustoma grandiflorum \\
\hline Marigold & Tagetes erecta \\
\hline Oriental larkspur & Consolida orientalis \\
\hline Oriental lily & Lilium Oriential hybrids \\
\hline Peony & Paeonia cultivars \\
\hline Phlox & Phlox paniculata \\
\hline Purple coneflower & Echinacea cultivars \\
\hline Ranunculus & Ranunculus asiaticus \\
\hline Rose & Rosa hybrids \\
\hline Snapdragon & Antirrbinum majus \\
\hline Statice & Limonium cultivars \\
\hline Stock & Matthiola incana \\
\hline Sunflower & Helianthus annuus \\
\hline Sweet pea & Lathyrus odorata \\
\hline Sweet william & Dianthus cultivars \\
\hline Tuberose & Polianthes tuberosa \\
\hline Tulip & Tulipa gesneriana \\
\hline Viburnum & Viburnum species \\
\hline Yarrow & Achillea cultivars \\
\hline Zinnia & Zinnia violacea \\
\hline
\end{tabular}

Table 2. Respondents to a 2017 survey regarding North American specialty cut flower production and postharvest issues were asked to report their job position with their company $(n=210)$.

\begin{tabular}{lc}
\hline Job position & $\begin{array}{c}\text { Respondents } \\
\text { (\%) }\end{array}$ \\
\hline Owner & 71.0 \\
Grower & 15.2 \\
Production manager & 1.9 \\
Floral designer & 0.5 \\
General manager & 0.5 \\
Sales representative & 0.5 \\
Other & 10.4 \\
\hline
\end{tabular}

format and did not use the same rank for more than one problem.
Production issues. The main production problem was insect management; disease management was the third most important problem (Fig. 3). Pest management is a common problem for many floriculture crops (Nelson, 1998). Cut flowers grown outdoors are subjected to a greater number of potential insects and diseases than what would normally be found in greenhouses.

Crop timing was the second most important production problem (Fig. $3)$. Timing problems included determining the correct harvest stage, harvest windows that were too short, flowering all at once, or lack of control when the crop was ready to harvest. Identifying the right harvest stage is important for increasing the postharvest life and avoiding postharvest problems. When flowers are harvested too late during development, they will have a shorter postharvest life and are more susceptible to damage during shipping and handling. If flowers are harvested too early, then the buds may never open or develop properly in the vase (Dole and Schnelle, 2004; Halevy and Mayak, 1979). When possible, flowers should be harvested in the tight bud stage to reduce mechanical injury and ethylene effects during transport (Armitage and Laushman, 2003). Furthermore, the harvest stage varies with the season, consumer preferences, and market distance. Flowers for direct sale are harvested at a more open stage than flowers destined for long-distance shipping (Nowak, 1990).

For many species, producers had issues controlling flowering; for example, either the whole crop flowered at once and had a short harvest window or the crop flowered irregularly. This can be due to weather or plant characteristics that make succession planting difficult, especially for perennials, such as peony, that are fieldgrown, and cool season crops, such as anemone, ranunculus, and sweet pea, that develop rapidly during warm periods. Controlling timing is important for ensuring a continuous supply and matching production with major holidays, such as the production of peony for Mother's Day. In the field, plastic mulches or row covers can be used to produce earlier harvests. High tunnels and greenhouses are used to produce cut flowers later in the fall and earlier in the spring, depending on 


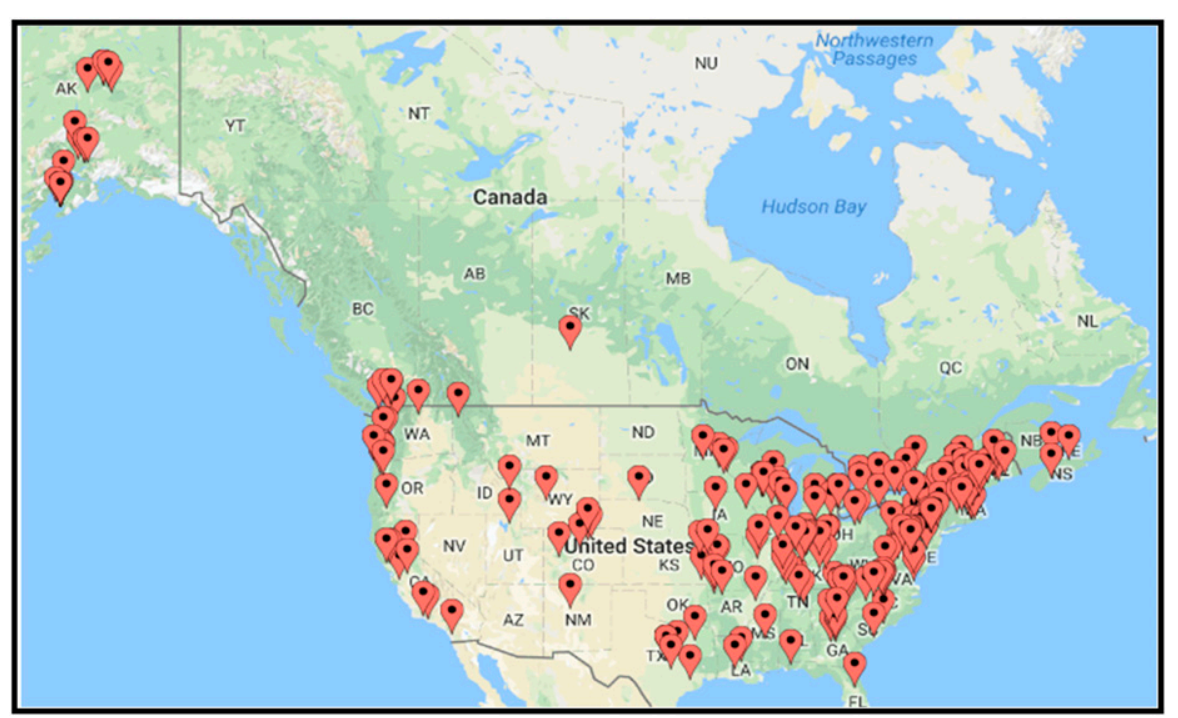

Fig. 1. Surveys were emailed to 1098 members (each business received only one survey request) of the Association of Specialty Cut Flower Growers (ASCFG), with a $19 \%$ response rate. Map shows the location of respondents in Canada and the United States $(n=210)$.

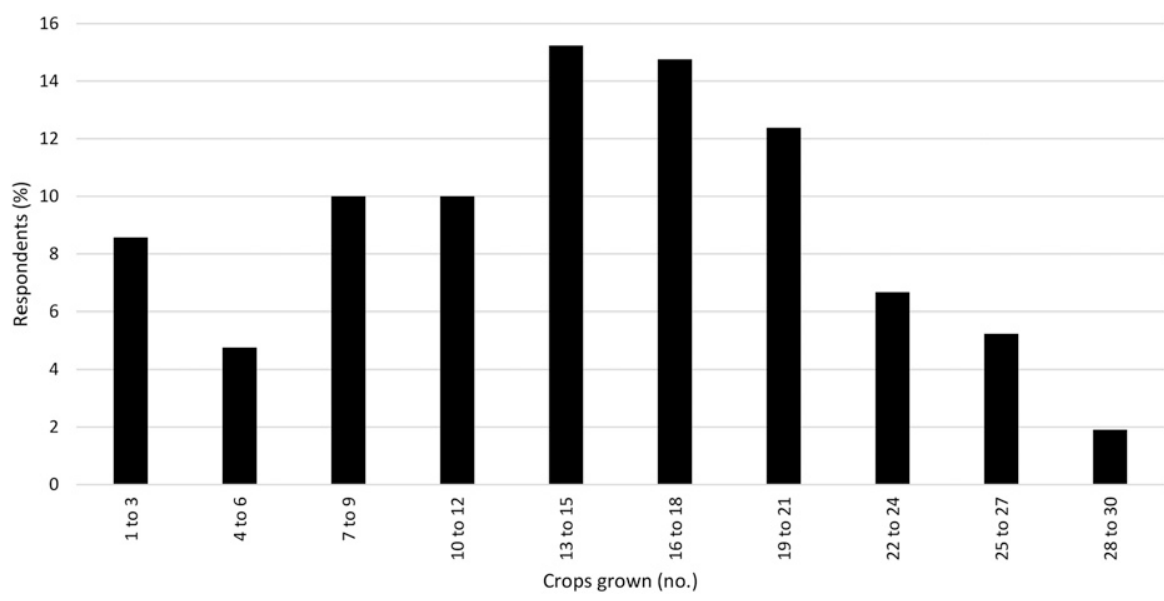

Fig. 2. Respondents to a 2017 survey regarding North American specialty cut flower production and postharvest issues were asked to mark the crops they produced. The chart shows the number of different crops produced by each respondent as a percent of total responses, including those who did not answer the question $(\mathrm{n}=\mathbf{2 1 0})$.

the crop species. Greenhouses offer better environmental control than high tunnels, but they are also more expensive to construct and maintain (Bogash et al., 2012; Byczynski, 2008).

Poor-quality propagation materials and insufficient demand were ranked the least most important issues (Fig. 3). The remaining production issues were of intermediate importance.

The most significant species-specific production problems (as reported by at least $10 \%$ of the respondents for at least two species) were timing the crop, stem length, and a number
Table 3. Respondents to a 2017 survey regarding North American specialty cut flower production and postharvest issues were asked about 31 flower species and which they produce. $^{\mathrm{z}}$

\begin{tabular}{|c|c|}
\hline Crop & Respondents (\%) \\
\hline Zinnia & 83.0 \\
\hline Peony & 75.0 \\
\hline Snapdragon & 74.5 \\
\hline Sunflower & 74.5 \\
\hline Dahlia & 73.9 \\
\hline Lisianthus & 63.8 \\
\hline Cockscomb & 63.3 \\
\hline Sweet william & 55.3 \\
\hline Ammi & 54.2 \\
\hline Cosmos & 52.7 \\
\hline Yarrow & 51.1 \\
\hline Hydrangea & 48.4 \\
\hline Larkspur & 47.9 \\
\hline Tulip & 47.3 \\
\hline Statice & 46.3 \\
\hline Stock & 46.3 \\
\hline Sweet pea & 46.3 \\
\hline Ranunculus & 44.7 \\
\hline Marigold & 41.0 \\
\hline Anemone & 40.0 \\
\hline Delphinium & 37.8 \\
\hline Lily & 36.7 \\
\hline Phlox & 33.0 \\
\hline Blue flossflower & 31.3 \\
\hline Tuberose & 29.3 \\
\hline Viburnum & 28.7 \\
\hline Gladiolus & 27.7 \\
\hline Purple coneflower & 27.1 \\
\hline Garden roses & 20.2 \\
\hline Calla & 16.5 \\
\hline Dutch iris & 11.2 \\
\hline
\end{tabular}

least commonly grown $(\mathrm{n}=188)$.

aforementioned species, the producers had issues controlling flowering; for example, either the whole crop flowered at once and had a short harvest window or the crop flowered irregularly. Another timing issue was identifying the right stage for harvesting cosmos, peony, sunflower, and tulip.

Stem length was a problem for the production of anemone $(24.1 \%)$, blue flossflower $(22.5 \%)$, lisianthus (for $17.1 \%)$, rose $(12.5 \%)$, stock $(34.1 \%)$, sweet pea $(26.5 \%)$, sweet william $(20.9 \%)$, and tulip (24.4\%). A number of the respondents only wrote "stem length" as a problem and did not specify if the problem was stems that were too short or stems that were too long. However, based on the other responses, it was assumed that they referred to stems 
Research Reports

Table 4. Respondents to a 2017 survey regarding North American specialty cut flower production and postharvest issues were asked to list additional cut flower species and categories they produce in addition to the 31 main species included in the survey $($ Table 3$) .^{\mathrm{z}}$

Respondents reported growing the indicated Common name

Scientific name

species or cut flower

Agrostemma

Allium

Alstroemeria

Amaranth

Artemisia

Aster

Bachelor buttons

Balloon plant

Baptisia

Basil

Beebalm

Bellflower

Bells of Ireland

Bittersweet

Blackberry

Black-eyed susan

Borage

Bupleurum

Butterfly weed

Celosia, plume

Centaurea

Chamomile

Chrysanthemum

Clematis

Gerbera

Daffodil

Dill

Dogwood

Dusty miller

Edible flowers

Eleagnus

Eucalyptus

Euphorbia

Feverfew

Queen of the prairie

Fillers

Flowering branches

Foliages

Forsythia

Foxglove

Freesia

Fritillaria

Ginger

Globe thistle

Gloriosa lily

Goldenrod

Gomphrena

Gooseneck loosestrife

Agrostemma githago

Allium cultivars

category (no.)

Alstroemeria cultivars

4

Amaranthus cruentus

4

Artemisia cultivars

Callistephus chinensis or

Aster cultivars

Centaurea cyanus

Gomphocarpus physocarpus 3

Baptisia cultivars

Ocimum cultivars

Monarda cultivars

Campanula medium

Moluccella laevis

Celatrus species

Rubus cultivars

Rudbeckia cultivars

Borago officinalis

Bupleurum rotundifolium

Asclepias cultivars

Celosia argenta plumosa group

Centaurea cultivars $\quad 2$

Matricaria cultivars 1

Chrysanthemum $\times$ grandiflorum $\quad 8$

Clematis cultivars $\quad 2$

Gerbera jamesonii 1

Narcissus cultivars $\quad 3$

Anethum graveolens $\quad 2$

Cornus cultivars 2

Senecio cineraria $\quad 3$

Elaeagnus cultivars 1

Eucalypus cultivars 11

Euphorbia cultivars 3

Tanacetum parthenium $\quad 2$

Filipendula cultivars $\quad 1$

3

Freesia hybrids 2

Fritillaria cultivars 1

Zingiberaceae 1

Echinops cultivars 1

Gloriosa superba 2

Solidago cultivars $\quad 2$

Gomphrena cultivars $\quad 7$

Lysimachia clethroides 1

Gramineae $\quad 14$

Gypsophila cultivars $\quad 1$

Heliopsis cultivars $\quad 1$

Helleborus cultivars $\quad 2$

Hellebores

Herbs 
Table 4. (Continued) Respondents to a 2017 survey regarding North American specialty cut flower production and postharvest issues were asked to list additional cut flower species and categories they produce in addition to the 31 main species included in the survey (Table 3$)^{z}$

\section{Common name}

Hibiscus, mahogany splendor

Holly

Honeywort

Hops

Hosta flowers

Hyacinths

Icelandic poppies

Japanese anemone

Lady's Mantle

Lilac

Love-in-the-mist

Mints

Mock orange

Mountain mint

Natives

Flowering tobacco

Ninebark

Orach

Ornamental cabbage/kale

Ornamental okra

Parsley

Penstemon

Perennials

Pineapple lily

Poppy

Quince

Raspberry

Red hot poker

Rose-hips

Sage

Satin flower

Scabiosa

Scented geraniums

Sedum

Shasta daisy

Smilax

St. John's wort

Sweetshrub

Trachelium

Tree peony

Verbena-on-a-stick

Vines

Wild carrot

Willow

Winterberry

Woody trees, shrubs, vines
Respondents reported growing the indicated species or cut flower

Scientific name category (no.)

Hibiscus acetosella

Ilex cultivars

2

Cerinthe major

Humulus Iupulus

Hosta cultivars

Hyacinthus orientalis

Papaver nudicaule

Anemone hupehensis

Alchemilla mollis

Syringa vulgaris

Nigella damascena

1

1

1

1

1

2

3

Mentha cultivars

Philadelphus cultivars

Pycnanthemum muticum

3

Nicotiana sylvestris

Physocarpus opulifolius

Atriplex hortensis

Brassica oleracea

Abelmoschus hybrids

Petroselinum crispum

Penstemon cultivars

Eucomis cultivars

Papaver cultivars

Chaenomeles cultivars

Rubus idaeus

Kniphofia uvaria

Rosa cultivars

Salvia cultivars

Clarkia amoena

Scabiosa atropurpurea or

S. caucasica

Pelargonium cultivars $\quad 5$

Crassulaceae 3

Leucanthemum cultivars 3

Smilax species 1

Hypericum cultivars 1

Calycanthus cultivars $\quad 1$

Trachelium caeruleum 1

Paeonia cultivars 1

Verbena bonariensis

Salix cultivars 1

Ilex decidua or I. verticillata 3

${ }^{\mathrm{z}}$ Ninety-nine species and categories were reported by respondents $(\mathrm{n}=81)$.

that were too short. Furthermore, no producer listed "long stems" as a problem because long stems can be readily cut to the correct length. Approximately $75 \%$ of the cut flower wholesalers prefer a stem length of at least $46 \mathrm{~cm}$, regardless of the species (Dole and Schnelle, 1993). The industry standards for preferred stem length vary by species and by location. For example, the minimum accepted stem length standard is 40 $\mathrm{cm}$ for imported roses, but it can be

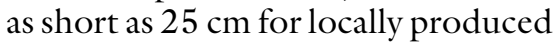
flowers or 50-59 cm for stock (Association of Floral Importers of Florida, 2009; Flowers Canada Growers, 1996). 


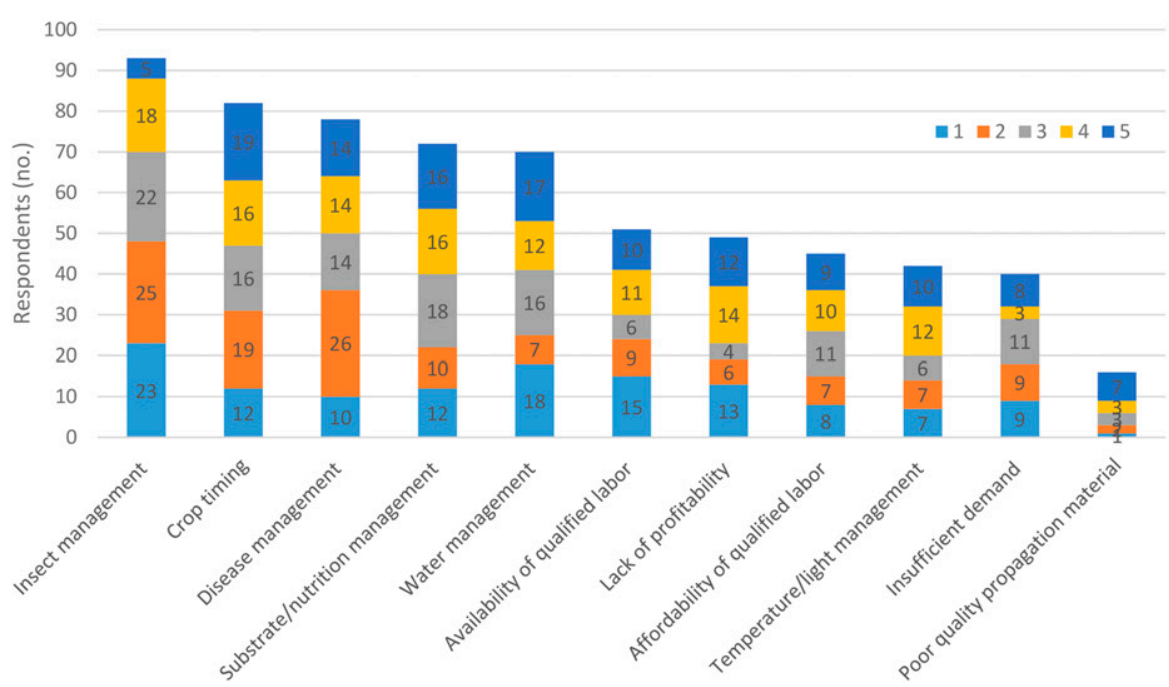

Fig. 3. Respondents to a 2017 survey regarding North American specialty cut flower production and postharvest issues were asked to select the five most important production issues for their business and rank them from 1 to 5 , with 1 being most important. Each number from 1 (most important) to 5 (least important) was used once for each respondent. Numbers in the bars are the number of times the ranking was recorded for each production issue $(n=128)$.

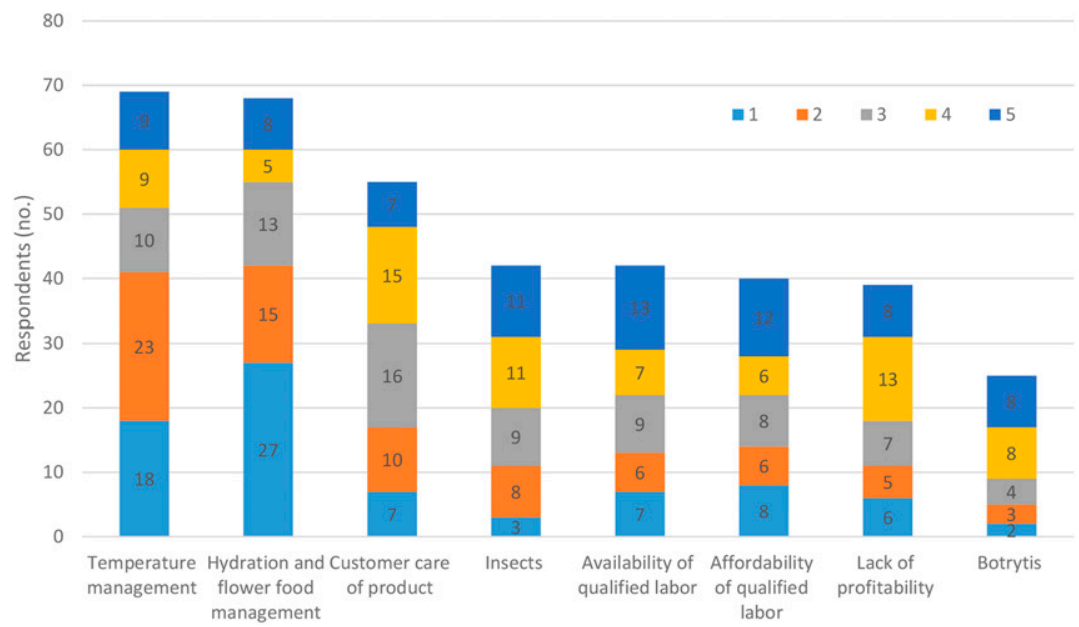

Fig. 4. Respondents to a 2017 survey regarding North American specialty cut flower production and postharvest issues were asked to select the first most important postharvest issues for their business and rank them from 1 to 5 , with 1 being most important. Each number from 1 (most important) to 5 (least important) was used once for each respondent. Numbers in the bars are the number of times the ranking was recorded for each postharvest issue $(n=76)$.

Animals were a significant production problem for dutch iris $(15.4 \%)$, lily $(11.9 \%)$, sunflower $(30.2 \%)$, tulip $(13.3 \%)$, and viburnum (11.1\%). Most of the problems with animals resulted in foliage and flower damage; however, in some cases, the animals ate the bulbs or seeds. Birds ate the berries during viburnum production. Rodents were a common problem because they eat seeds and bulbs both indoors and outdoors. three of the most important to respondents were aphids, beetles, and thrips.

Aphids were a significant problem during the production of ranunculus (19.2\%) and snapdragon (14.3\%). Aphids are a common insect that can be very damaging in high populations because they cause distortion and curling of leaves, buds, and shoots. In addition to the damage caused by feeding, aphids can also be a vector for various pathogenic viruses (Zhu et al., 2014).

Several types of beetles were significant problems for dahlia (14.2\%), marigold (12.2\%), and rose (16.7\%). For dahlias, respondents reported issues with cucumber, flea, and japanese beetles; however, blister and japanese beetles were problems for marigold and cucumber. The japanese beetles were problems for roses. Not surprisingly, lily beetles were also an important pest for lilies. Beetles consume and disfigure the foliage and sometimes the flower petals (Moore and Bradley, 2018). Because they often occur in large numbers, the damage can be extensive.

Thrips were a significant problem during the production of dahlia (12.1\%) and gladiolus $(32.1 \%)$. Thrips cause distortion of new growth and silvery streaks in flowers and foliage. Western flower thrips are especially troublesome because they transmit tomato spotted wilt and impatiens necrotic spot viruses (Mouden et al., 2017).

Among the plant diseases listed, powdery mildew was a significant problem for the production of phlox (18.8\%) and zinnia (29.8\%), and root rot and soft rot were significant problems for calla (14.3\%) and lisianthus $(10 \%)$. Powdery mildew is one of the most serious issues with zinnia production (Spooner et al., 1991). Powdery mildew is a white powdery growth that typically occurs on the upper side of leaves and can be especially damaging when it develops in young tissue. Infected plants have reduced vigor and distorted new growth (Hoshi et al., 2013). Various types of crown rot and soft rot are the most common problem for callas, with bacterial soft rot being the most important (Kuehny, 2000). Root rot and crown rot are also major problems for lisianthus, and there are no known resistant cultivars (Harbaugh and McGovern, 2000). 
Table 5. Respondents to a 2017 survey regarding North American specialty cut flower production and postharvest issues were asked to identify their production challenges with 31 crop species. ${ }^{z}$

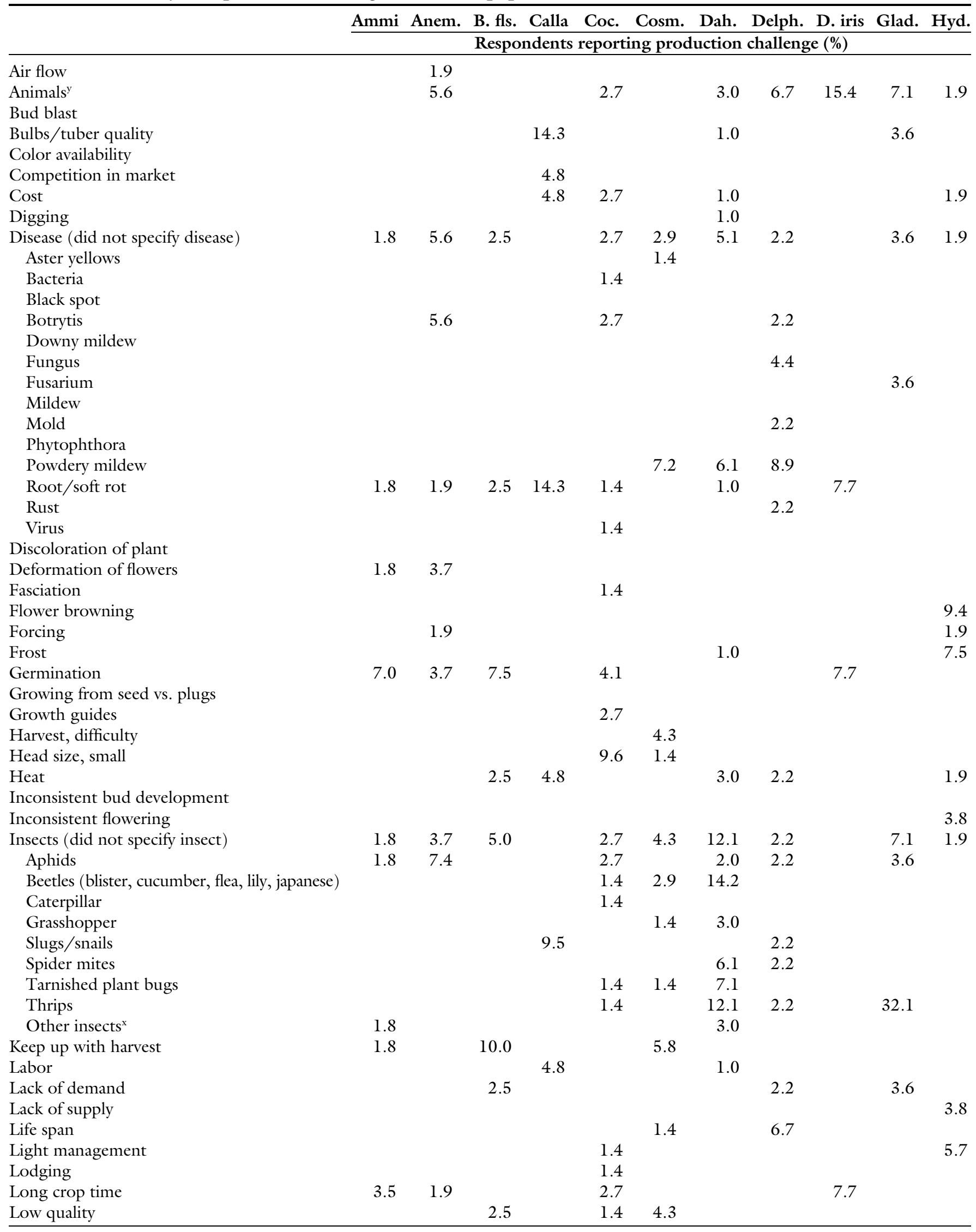

(Continued on next page) 
Table 5. (Continued) Respondents to a 2017 survey regarding North American specialty cut flower production and postharvest issues were asked to identify their production challenges with 31 crop species. ${ }^{\mathrm{z}}$

Ammi Anem. B. fls. Calla Coc. Cosm. Dah. Delph. D. iris Glad. Hyd. Respondents reporting production challenge (\%)

Low yield

Nutrient management

Obtaining more desirable cultivars

Overwintering

Pests

Pinching

Planting

Processing

Propagation

Requirements of the different cultivars

Seeding

Selecting doubles

Shattering

Short season

Spacing

Spotting

Stem bending

Stem cracking/splitting

Stem length

Storage

Successions

Support

Temperature management

Timing

Transplanting

Water management

Weak stems/necks

Weather

Weeds

Wilting

Wind

None

No response

Total respondents who grow each crop (no.)
2.5

4.8

1.9

1.9

5.3

5.3

$$
3.7
$$

$\begin{array}{ll}7.0 & 24.1\end{array}$

22.5

9.5
4.8

1.8

7.4

$\begin{array}{ll}3.5 & 16.7\end{array}$

7.4
6.7

1.9

1.8

1.8

31.6

22.8
2.5

2.5 9

2.5

1.4

4.8

1.4

1.4

1.0

1.4

3.0

4.4

6.7

4.4

4.4

1.9

${ }^{z}$ Of the 31 species, ammi, anemone (Anem.), blue flossflower (B. fls.), calla, cockscomb (Coc.), cosmos (Cosm.), dahlia (Dah.), delphinium (Delph.), dutch iris (D. iris), gladiolus (Glad.), and hydrangea (Hyd.) are included here (see Tables 6 and 7 for remaining species). The number listed is the percentage of respondents who reported the issue for each species. Some respondents reported multiple production issues for a species ( $\mathrm{n}=21-139$, depending on the cut flower species).

${ }^{y}$ Animal category includes all vertebrate species, including birds (Canada geese and other species), chipmunks, deer, gophers, mice, rabbits, rats, squirrels, voles, and woodchucks.

${ }^{\mathrm{x}}$ Other insects include earwigs (dahlia), stemborers (dahlia), and whiteflies (ammi).

Other notable species-specific problems (listed by $20 \%$ or more of respondents for one species) were low yield in the production of tuberose $(31.8 \%)$ and disease in the production of roses $(20.8 \%)$. Although reduced yield in tuberose may have been due to a variety of causes, two possible causes included the southern root-knot nematode, which has been responsible for up to a $10 \%$ reduction in yield (Saha and Khan, 2016) and fusarium, which has also been shown to greatly decrease yield (Muthukumar et al., 2006). Multiple diseases affect greenhouse production of roses, such as powdery mildew and botrytis (Bout et al.,
2010). Although many respondents noted diseases in general without listing a specific disease, black spot was a disease specifically mentioned by respondents.

Germination was a significant problem in the production of larkspur for $20 \%$ of respondents. Increasing temperature accelerates germination of larkspur, depending on the cultivar and length of exposure (Mori, 2006). However, other sources showed that oriental larkspur germinates better at lower temperatures $\left(5 / 10^{\circ} \mathrm{C}\right.$ and $5 / 15^{\circ} \mathrm{C}$ day/ night temperatures) compared with germination at $10 / 20{ }^{\circ} \mathrm{C}$ (Torra et al., 2015).
Postharvest issues on the FARM. When considering all the postharvest issues, temperature management, hydration, and flower food management, and customer care of the product were the most important issues (Fig. 4). Cooling of cut flowers reduces the respiration rate; therefore, all metabolic activities are diminished and carbohydrates are preserved. Cold processing and storage are essential for increasing postharvest life for most cut flowers and foliage. Precooling is a very important step for achieving low-temperature storage and transportation. The optimal temperature is usually 2 to $3^{\circ} \mathrm{C}$, except for species such as celosia, oriental lilies, and zinnias, which 
Table 6. Respondents to a 2017 survey regarding North American specialty cut flower production and postharvest issues were asked to identify their production challenges with 31 crop species. ${ }^{\mathrm{z}}$

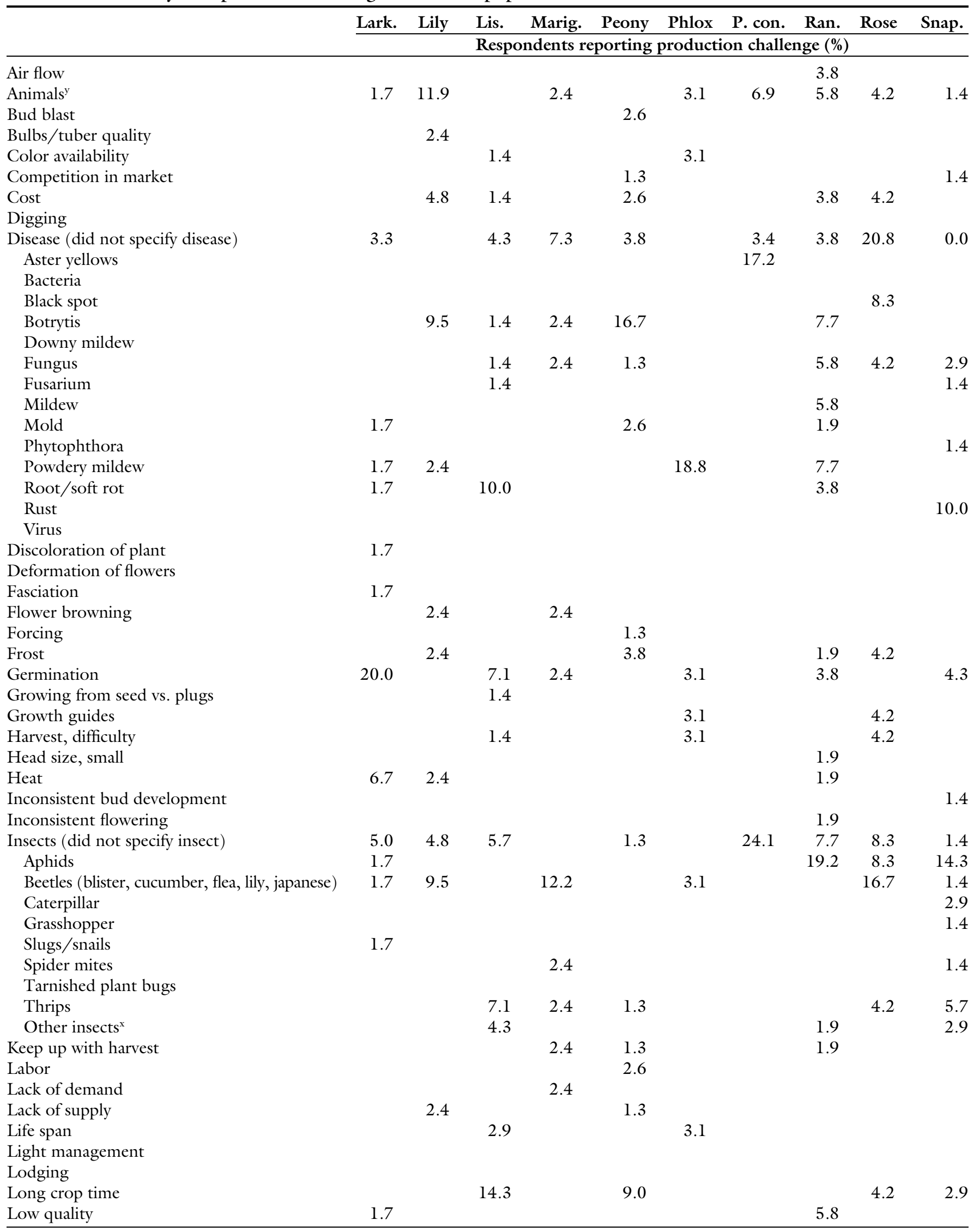


Table 6. (Continued) Respondents to a 2017 survey regarding North American specialty cut flower production and postharvest issues were asked to identify their production challenges with 31 crop species. ${ }^{\mathrm{z}}$

\begin{tabular}{|c|c|c|c|c|c|c|c|c|c|c|}
\hline & Lark. & Lily & Lis. & Marig. & Peony & Phlox & P. con. & Ran. & Rose & Snap. \\
\hline & \multicolumn{10}{|c|}{ Respondents reporting production challenge (\%) } \\
\hline Low yield & & & 1.4 & & & & 3.4 & & & 1.4 \\
\hline Nutrient management & & & 1.4 & & 5.1 & & & 3.8 & & 1.4 \\
\hline Obtaining more desirable cultivars & & & & 2.4 & 1.3 & & & & & 2.9 \\
\hline Overwintering & 3.3 & & 1.4 & & & & 3.4 & & 4.2 & 1.4 \\
\hline \multicolumn{11}{|l|}{ Pests } \\
\hline \multicolumn{11}{|l|}{ Pinching } \\
\hline \multicolumn{11}{|l|}{ Planting } \\
\hline Processing & & 2.4 & & & & & & & & \\
\hline Propagation & 1.7 & & & & & & & & & \\
\hline \multicolumn{11}{|l|}{ Requirements of the different cultivars } \\
\hline Seeding & 8.3 & & & & & & 3.4 & & & 1.4 \\
\hline \multicolumn{11}{|l|}{ Selecting doubles } \\
\hline Shattering & & & & & 1.3 & 3.1 & & & & \\
\hline Short season & & & & & & 3.1 & & & & \\
\hline Spacing & 1.7 & 4.8 & & & & & & & & \\
\hline Spotting & & & 1.4 & & & & & & & \\
\hline Stem bending & & & & & & & & & & 1.4 \\
\hline Stem cracking/splitting & & & 1.4 & & & & & & & 1.4 \\
\hline Stem length & 3.3 & & 17.1 & 4.9 & & 6.3 & 6.9 & 9.6 & 12.5 & 8.6 \\
\hline \multicolumn{11}{|l|}{ Storage } \\
\hline Successions & 6.7 & 2.4 & 5.7 & & & & & 1.9 & & 7.1 \\
\hline Support & & & 4.3 & & & & & & & 5.7 \\
\hline Temperature management & 1.7 & & & & 1.3 & & & 13.5 & 4.2 & \\
\hline Timing & 6.7 & 9.5 & 5.7 & & 15.4 & 9.4 & 3.4 & 17.3 & 4.2 & 2.9 \\
\hline Transplanting & 1.7 & & & & & & & & & \\
\hline Water management & & & 5.7 & & 2.6 & & & 3.8 & & \\
\hline Weak stems/necks & & & & 14.6 & & 3.1 & & & & 8.6 \\
\hline Weather & & & & & 2.6 & & & & 4.2 & \\
\hline Weeds & 5.0 & & 2.9 & & 12.8 & & & & & \\
\hline Wilting & 1.7 & & 2.9 & & 1.3 & & & & & \\
\hline Wind & 1.7 & & 1.4 & & 1.3 & & & 1.9 & & 1.4 \\
\hline None & 6.7 & 7.1 & 5.7 & 14.6 & 5.1 & 18.8 & 17.2 & 1.9 & 4.2 & 11.4 \\
\hline No response & 11.7 & 19.0 & 10.0 & 22.0 & 10.3 & 18.8 & 17.2 & 11.5 & 12.5 & 14.3 \\
\hline Total respondents who grow each crop (no.) & 90 & 69 & 120 & 77 & 141 & 62 & 51 & 84 & 38 & 7140 \\
\hline
\end{tabular}

${ }^{\mathrm{z}}$ Of the 31 species, larkspur (Lark.), lily, lisianthus (Lis.), marigold (Marig.), peony, phlox, purple coneflower (P. con.), ranunculus (Ran.), rose, and snapdragon (Snap.) are included here (see Tables 5 and 7 for the remaining species). The number listed is the percentage of respondents who reported the issue for each species. Some respondents reported multiple production issues for a species ( $\mathrm{n}=38-141$, depending on the cut flower species).

${ }^{y}$ Animal category includes all vertebrate species, including birds (canada geese and other species), chipmunks, deer, gophers, mice, rabbits, rats, squirrels, voles, and woodchucks.

${ }^{x}$ Other insects include leafcutting bee (lisianthus), mealybug (lisanthus), symphylans (ranunculus), and shield bug (snapdragon).

should be kept at 4 to $7^{\circ} \mathrm{C}$ to prevent cold damage (Dole et al., 2017b; Sun and Brosnan, 1999).

Hydration refers to the proper water uptake by cut stems, especially immediately after harvest. Commercial hydration solutions promote water uptake and reduce the amount of microbial growth in the stems. Water quality, mineral content, and $\mathrm{pH}$ are important factors in the uptake of water solution. Water with a lower $\mathrm{pH}$ prevents the growth of microorganisms and is more easily absorbed by the stem (Ahmad et al., 2013 ). Flower food management refers to the supply of carbohydrates to the cut flower to aid in replenishing the consumed sugars (Dole et al., 2017b).

Botrytis was the least important issue (Fig. 4). The remaining postharvest issues, insect management, availability and affordability of qualified labor, and lack of profitability, were of intermediate importance.

The most significant speciesspecific postharvest problems at the farm, as reported by at least $10 \%$ of the respondents, were hydration, shattering, stripping leaves/thorns, temperature management, timing, vase life, weak stems, and zinnia meltdown (Tables 8-10). Hydration was a problem for the postharvest of blue flossflower (10.0\%), delphinium (11.1\%), hydrangea $(28.3 \%)$, viburnum (16.7\%), and yarrow $(20 \%)$. None of these species hydrate easily after harvest, and a small percentage of flowers often remain wilted. Hydration recommendations for hydrangea include recutting the end of the stems and placing them in warm water ( 100 to $120^{\circ} \mathrm{F}$ ) or using a commercial hydration solution (Dole et al., 2017b); for the stems that do not rehydrate, the stems should be recut and the process should be repeated.

Petal shattering was a problem during the postharvest of phlox $(15.6 \%)$. Phlox flowers are ethylenesensitive, and petal abscission can be 
Table 7. Respondents to a 2017 survey regarding North American specialty cut flower production and postharvest issues were asked to identify their production challenges with 31 crop species. ${ }^{z}$

Stat. Stock. Sunf. S. pea. S. will. Tuber. Tulip. Vib. Yar. Zinnia Respondents reporting production challenge (\%)

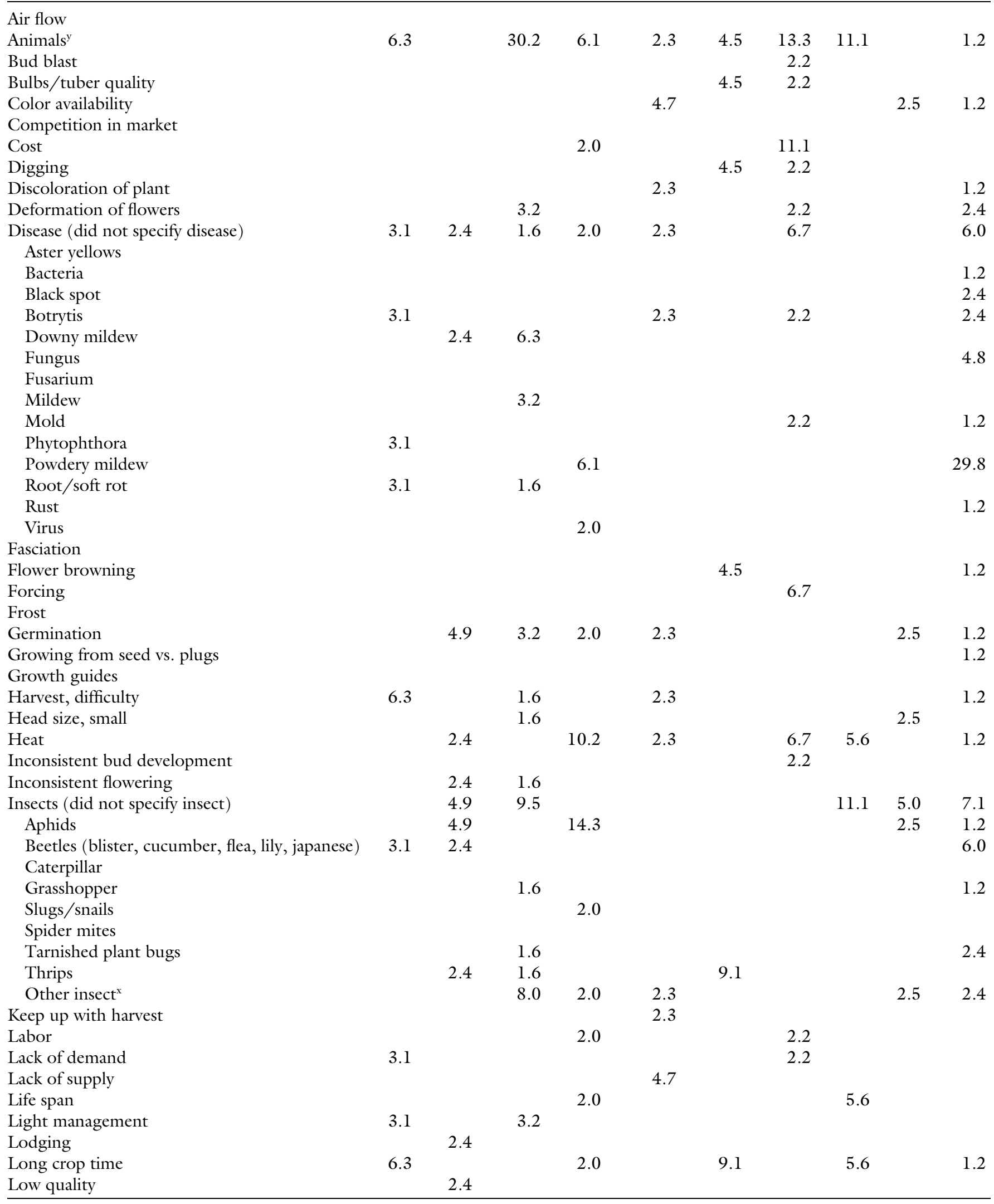


Table 7. (Continued) Respondents to a 2017 survey regarding North American specialty cut flower production and postharvest issues were asked to identify their production challenges with 31 crop species. ${ }^{\mathrm{z}}$

\begin{tabular}{|c|c|c|c|c|c|c|c|c|c|c|}
\hline & Stat. & Stock. & Sunf. & S. pea. & & Tuber. & Tulip. & Vib. & Yar. & Zinnia \\
\hline & \multicolumn{10}{|c|}{ Respondents reporting production challenge (\%) } \\
\hline Low yield & 9.4 & 7.3 & & & & 31.8 & & & & 1.2 \\
\hline Nutrient management & 3.1 & & 1.6 & 4.1 & & & & & & 1.2 \\
\hline Obtaining more desirable cultivars & & 4.9 & 1.6 & & & & & & & 1.2 \\
\hline Overwintering & & 2.4 & & & 4.7 & & & & & \\
\hline Pests & & & & & & & 2.2 & & & 1.2 \\
\hline \multicolumn{11}{|l|}{ Pinching } \\
\hline Planting & & & 1.6 & & & & 2.2 & & 2.5 & \\
\hline \multicolumn{11}{|l|}{ Processing } \\
\hline Propagation & & 2.4 & & & & & & & & \\
\hline Requirements of the different cultivars & & & 3.2 & & & & & & & \\
\hline Seeding & & & 1.6 & 2.0 & & & & & & 6.0 \\
\hline Selecting doubles & & 12.2 & & & & & & & & 4.8 \\
\hline Shattering & & & & 6.1 & & & & & & \\
\hline Short season & & 2.4 & & & & & & & & \\
\hline Spacing & & & 3.2 & & & & 2.2 & & & \\
\hline \multicolumn{11}{|l|}{ Spotting } \\
\hline \multicolumn{11}{|l|}{ Stem bending } \\
\hline \multicolumn{11}{|l|}{ Stem cracking/splitting } \\
\hline Stem length & & 34.1 & & 26.5 & 20.9 & & 24.4 & & 7.5 & \\
\hline Storage & & & & & & 4.5 & & & & 1.2 \\
\hline Successions & & & 7.9 & & 2.3 & & 2.2 & & & \\
\hline Support & & 2.4 & & 14.3 & & & & & 2.5 & \\
\hline Temperature management & & & & 4.1 & 2.3 & & 2.2 & & & \\
\hline Timing & & 14.6 & 15.9 & 12.2 & 7.0 & 4.5 & 15.6 & 5.6 & 7.5 & 1.2 \\
\hline Transplanting & & & & 2.0 & & & & & & \\
\hline Water management & 6.3 & 2.4 & 3.2 & 2.0 & 2.3 & & & 5.6 & & 1.2 \\
\hline Weak stems/necks & & 9.8 & 1.6 & & 9.3 & & 2.2 & & & 4.8 \\
\hline Weather & & 2.4 & 4.8 & 2.0 & & & & & & \\
\hline Weeds & & & & & & 9.1 & & & 7.5 & 1.2 \\
\hline Wilting & & & & & & & & & 2.5 & \\
\hline Wind & 3.1 & 2.4 & 3.2 & & & & & & & 1.2 \\
\hline None & 25.0 & 9.8 & 12.7 & 8.2 & 27.9 & 22.7 & 6.7 & 38.9 & 32.5 & 4.8 \\
\hline No response & 12.5 & 4.9 & 6.3 & 4.1 & 4.7 & 4.5 & 8.9 & 22.2 & 22.5 & 17.9 \\
\hline Total respondents who grow each crop (no.) & 87 & 87 & 140 & 87 & 104 & 55 & 89 & 54 & 96 & 156 \\
\hline
\end{tabular}

${ }^{\mathrm{z}}$ Of the 31 species, statice (Stat.), stock, sunflower (Sunf.), sweet pea (S. pea), sweet william (S. will.), tuberose (Tuber.), tulip, viburnum (Vib.), yarrow (Yar.), and zinnia are included here (see Tables 5 and 6 for the remaining species). The number listed is the percentage of respondents who reported the issue for each species. Some respondents reported multiple production issues for a species ( $\mathrm{n}=54-156$, depending on the cut flower species).

${ }^{y}$ Animal category includes all vertebrate species, including birds (canada geese and other species), chipmunks, deer, gophers, mice, rabbits, rats, squirrels, voles, and woodchucks.

${ }^{\mathrm{x}}$ Other insects include armyworm (sunflower), corn root worm (sunflower), earwigs (sunflower, zinnia), lygus bug (sunflower), spittle bugs (sweet pea, yarrow), stem borers (zinnia), sunflower worm (sunflower), symphylans (sweet pea).

accelerated by ethylene (Patterson and Bleecker, 2004). Ethylene inhibitors such as 1-methylcyclopropene, silver thiosulfate, and aminoethoxyvinylglycine are effective for extending cut flower longevity and decreasing ethylene effects (Tanase et al., 2009). Furthermore, exogenous sugars, such as those in flower foods, also delay the production of endogenous ethylene (van Doorn, 2004).

Not surprisingly, stripping leaves and thorns from stems were listed as problems by rose producers (16.7\%). The presence of thorns on the stems requires care when harvesting and handling cut roses.
Temperature management was a problem during the postharvest of peony $(11.5 \%)$. By "temperature management," the respondents primarily meant that they had difficulty maintaining the appropriate temperature during the processing, storage, and transporting of peonies. Cut peony buds can open quickly, unless they are kept cold. After harvest, buds should be immediately cooled to 33 to $34^{\circ} \mathrm{F}$, and that temperature should be maintained during the many postharvest handling stages (Kamenetsky and Dole, 2012). Furthermore, bud maturity influences the peony response to different temperatures (Eason et al.,
2002). Another complaint of producers was the short harvest window, which resulted in the harvest of many stems at once and insufficient cold storage space. Peony is typically a field-grown perennial because the plants need cold treatment and a long period of establishment before they can be commercially productive (Abbey, 2015 ). Because peony flowers open quickly at warm temperatures, periods of hot weather lead to the problems of short harvest windows, high numbers of cut stems at one time, and a lack of storage space.

Timing was a problem during the postharvest of dutch iris (15.4\%). As 
Table 8. Respondents to a 2017 survey regarding North American specialty cut flower production and postharvest issues were asked to identify their on-farm postharvest challenges with 31 crop species. ${ }^{2}$

Ammi Anem. B. fls. Calla Coc. Cosm. Dah. Delph. D. iris Glad. Hyd. Respondents reporting postharvest challenge (\%)

\begin{tabular}{|c|c|c|c|c|c|c|c|c|c|c|c|}
\hline \\
\hline \multicolumn{12}{|l|}{$\begin{array}{l}\text { Botrytis } \\
\text { Bulky }\end{array}$} \\
\hline Color fading & & 1.9 & & & & & & & & & \\
\hline Damage & & 1.9 & & 4.8 & & & & & & & \\
\hline Disease (did not specify disease) & & & & & 1.4 & & & & & & \\
\hline Fail to open/takes long time to open & & & & & & & 1.0 & & & & \\
\hline Harvest & 3.5 & & & & & 2.9 & 1.0 & & & & \\
\hline Holding & & 3.7 & 2.5 & & 1.4 & 1.5 & 1.0 & 2.2 & 7.7 & 3.6 & 1.9 \\
\hline Hydration & 7.0 & 1.9 & 10.0 & & 1.4 & 2.9 & 3.0 & 11.1 & & & 28.3 \\
\hline Insects (did not specify insects) & & & & & & 1.5 & 2.0 & & & & \\
\hline Necks snap/bend & & & & & 1.4 & & & & & & 1.9 \\
\hline Organic practices & & & & & & & 1.0 & & & & \\
\hline Packaging & & & & & & & & & & 3.6 & \\
\hline Petals browning & & 1.9 & & & 1.4 & & 1.0 & & & & 1.9 \\
\hline Powdery mildew & & & & & & & & 2.2 & & & \\
\hline Processing & & & & & & & 2.0 & & & & \\
\hline Shattering & 3.5 & 1.9 & & & & & 1.0 & 6.7 & & & \\
\hline Split stems & & 1.9 & & 9.5 & & & & & & & \\
\hline \multicolumn{12}{|l|}{ Spotted foliage } \\
\hline Stem bending & & 1.9 & & & & & & & & & \\
\hline Stem length & & 1.9 & & & & & & & & & 1.9 \\
\hline Storage & & & & & & & 2.0 & & & & \\
\hline \multicolumn{12}{|l|}{ Stripping leaves/thorns } \\
\hline Temperature management & 3.5 & 1.9 & & & 1.4 & 1.5 & 2.0 & & & 3.6 & 3.8 \\
\hline Timing & 5.3 & & 2.5 & & 2.7 & 4.3 & 3.0 & & 15.4 & 3.6 & 7.5 \\
\hline Thrips & & & & & & & 1.0 & & & & \\
\hline Vase life & 1.8 & 1.9 & & & & 14.5 & 16.2 & & 7.7 & & 3.8 \\
\hline Weak stem & & & & 4.8 & & 1.5 & & 11.1 & & & 1.9 \\
\hline None & 19.3 & 13.0 & 17.5 & 4.8 & 21.9 & 11.6 & 3.0 & 8.9 & 23.1 & 17.9 & 5.7 \\
\hline No response & 56.1 & 66.7 & 67.5 & 76.2 & 67.1 & 58.0 & 64.6 & 57.8 & 46.2 & 67.9 & 41.5 \\
\hline Total respondents who grow/handle & 102 & 75 & 59 & 31 & 119 & 99 & 139 & 71 & 21 & 52 & 91 \\
\hline
\end{tabular}

${ }^{\mathrm{z}}$ Of the 31 species, ammi, anemone (Anem.), blue flossflower (B. fls.), calla, cockscomb (Coc.), cosmos (Cosm.), dahlia (Dah.), delphinium (Delph.), dutch iris (D. iris), gladiolus (Glad.), and hydrangea (Hyd.) are included here (see Tables 9 and 10 for the remaining species). The number listed is the percentage of respondents who reported the issue for each species. Some respondents reported multiple production issues for a species $(\mathrm{n}=21-139$, depending on cut flower species).

previously mentioned, it is very important to harvest the crop at the optimum developmental stage to provide a quality product, long postharvest life, and easy transportation. The harvest stage varies greatly among species. Dutch iris should be harvested before the falls (downward petals in the inflorescence) reflex and standards (upright petals) expand (Dole and Wilkins, 2005; Eason et al., 2002).

Vase life was a problem for the postharvest of cosmos (14.5\%), dahlia (16.2\%), and viburnum (11.1\%). Vase life refers to the short postharvest life. Multiple factors can decrease postharvest life, such as lack of water uptake, microorganisms, low carbohydrate levels, ethylene, high respiration rates, and disease. Due to the variability of factors involved, there is no simple solution to increasing vase life. However, possible solutions include recutting stems, flower foods and preservatives, ethylene inhibitors, and cold storage (Siddiqui, 2015). The short postharvest life of cut flowers has emerged as one of the most important issues of the cut flower industry. Proper postharvest care has to be provided at every step of the marketing chain to maximize the vase life of cut flowers (Dole et al., 2017b).

Weak stems were a problem during the postharvest of delphinium (11.1\%). Respondents reported that delphinium stems break easily during handling. Among the important characteristics of the stems for cut flower production are length, toughness, shape, and branching. Toughness, also called mechanical strength, is important because it not only helps prevent lodging but also helps prevent bending and breaking of the inflorescence stem during postharvest handling and transportation (Zhao et al., 2013). Research work has been invested in increasing the mechanical strength of cut flowers such as peonies by using calcium sprays, day/ night temperature differentials, photosynthetic photon flux, and silicon applications, but more work is necessary to address the applicability of such treatments to other crops such as delphinium (Davies et al., 2002; Zhao et al., 2012, 2013).

Zinnia meltdown is an enigmatic disorder that was reported as a problem by $11.1 \%$ of respondents; it can be common some years and absent during other years (Dole et al., $2017 \mathrm{~b}$ ). This disorder is generally exhibited within 1 or 2 days after 
Table 9. Respondents to a 2017 survey regarding North American specialty cut flower production and postharvest issues were asked to identify their on-farm postharvest challenges with 31 crop species. ${ }^{\mathrm{z}}$

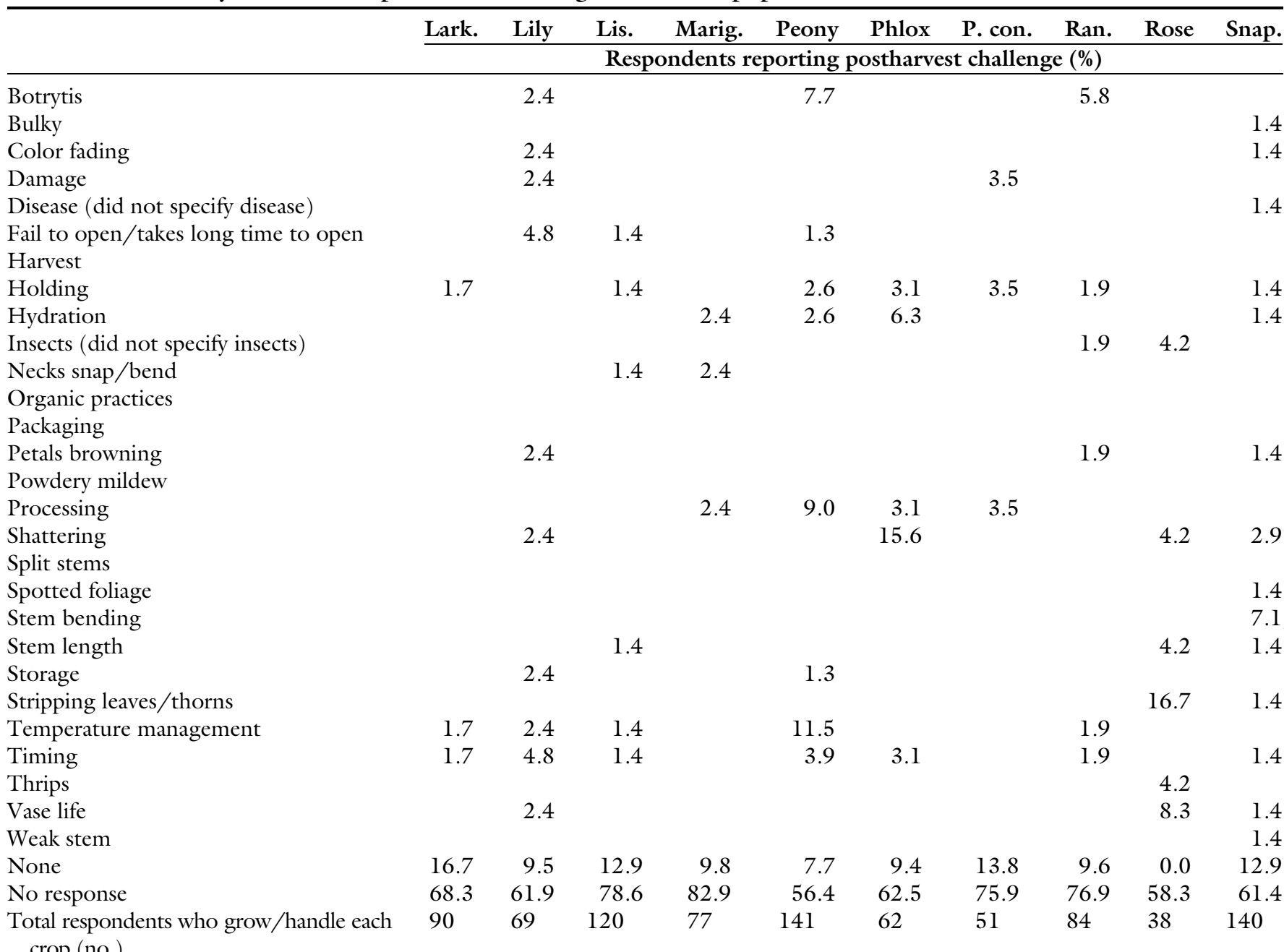
crop (no.)

${ }^{\mathrm{z}}$ Of the 31 species, larkspur (Lark.), lily, lisianthus (Lis.), marigold (Marig.), peony, phlox, purple coneflower (P. con.), ranunculus (Ran.), rose, and snapdragon (Snap.) are included here (see Tables 8 and 10 for the remaining species). The number listed is the percentage of respondents who reported the issue for each species. Some respondents reported multiple production issues for a species $(\mathrm{n}=38-141$, depending on the cut flower species).

harvest when the lower stem rots and collapses. Zinnia meltdown occurs primarily in the eastern United States; although the exact cause is still unknown, it is thought to be microbial in origin.

Postharvest issues DURING TRANSPORTATION/STORAGE. The most significant postharvest problems during transportation or storage of the cut flowers as reported by at least $10 \%$ of the respondents were damage, flowers opening, hydration, shattering, temperature management, vase life, and weak stems (Tables 11-13). Physical damage to flower petals or buds was a major problem during postharvest handling of dahlia (11.1\%), gladiolus (14.3\%), and lily (16.7\%). Cut flowers are a highly perishable commodity; they need to have excellent quality to be marketable. Any damage may render the product unmarketable. Proper postharvest handling of cut flowers minimizes damage to the flowers and increases postharvest life. Cut flowers are packed in bunches, sleeved, and put in boxes to prevent the movement of the product during transport and to allow for faster cooling (Reid, 2006).

Flower opening during transportation was a problem for the postharvest of dutch iris $(15.4 \%)$. Cut flowers are often harvested during the bud stage to withstand the rigors of transportation and maximize postharvest life. The mechanism of flower opening depends on cell expansion and varies widely between species. Several species of Iridaceae require growth of the pedicel for flower opening (van Doorn and Meeteren, 2003). Multiple hormones are involved in the flower opening process, including ethylene, gibberellin, jasmonic acid, and auxin. External factors such as light, water supply, carbohydrate supply, and temperature can also affect flower opening (van Doorn and Kamdee, 2014).

Hydration was a problem during the postharvest of blue flossflower $(10.0 \%)$, hydrangea (11.3\%), and viburnum (16.7\%), and shattering and dropping of petals were recorded for larkspur (10\%). The latter is an ethylene-mediated issue (Dole et al., 2017b). Temperature management of peony was a major issue for $16.7 \%$ of respondents. 
Table 10. Respondents to a 2017 survey regarding North American specialty cut flower production and postharvest issues were asked to identify their on-farm postharvest challenges with 31 crop species. ${ }^{2}$

\begin{tabular}{|c|c|c|c|c|c|c|c|c|c|c|}
\hline & Stat. & Stock & Sunf. & S. pea & S. will. & Tuber. & Tulip & Vib. & Yar. & Zinnia \\
\hline & \multicolumn{10}{|c|}{ Respondents reporting postharvest challenge (\%) } \\
\hline Botrytis & & & & & & & 2.2 & & & \\
\hline Bulky & & & 3.2 & & & & & & & \\
\hline \multicolumn{11}{|l|}{ Color fading } \\
\hline Damage & & & & & & & & & & 2.4 \\
\hline Disease (did not specify disease) & & & & & & & & & & $11.9^{\mathrm{y}}$ \\
\hline Fail to open/takes long time to open & & & & & 2.3 & & & & & \\
\hline Harvest & & & & 2.0 & & & & & & \\
\hline Holding & & & 1.6 & & & & 2.2 & 5.6 & 2.5 & 3.6 \\
\hline Hydration & & 2.4 & 6.3 & 2.0 & & & & 16.7 & 20.0 & 7.1 \\
\hline Insects (did not specify insects) & & & 1.6 & & & & & & & \\
\hline Necks snap/bend & & & & & & & & & & 3.6 \\
\hline Organic practices & & & & & & & & & & 1.2 \\
\hline Packaging & & & & & & & & & & 1.2 \\
\hline Petals browning & & & & & & & & & & 2.4 \\
\hline Powdery mildew & & & & & & & & & & 1.2 \\
\hline Processing & & & 1.6 & & & & & & & \\
\hline Shattering & & & 1.6 & 2.0 & & & & 5.6 & & \\
\hline \multicolumn{11}{|l|}{ Split stems } \\
\hline Spotted foliage & & & & & 2.3 & & & & & \\
\hline \multicolumn{11}{|l|}{ Stem bending } \\
\hline Stem length & & 2.4 & & 2.0 & & & 2.2 & & & \\
\hline Storage & & & 1.6 & & & & 6.7 & & & 1.2 \\
\hline Stripping leaves/thorns & & & & & 4.7 & & & & & \\
\hline Temperature management & 3.1 & 2.4 & 1.6 & 2.0 & & & & & & 3.6 \\
\hline Timing & & 2.4 & 3.2 & 4.1 & & & 2.2 & & 5.0 & 1.2 \\
\hline \multicolumn{11}{|l|}{ Thrips } \\
\hline Vase life & & & & 8.2 & & & & 11.1 & 2.5 & 9.5 \\
\hline Weak stem & & 2.4 & & & 4.7 & & 2.2 & & & \\
\hline None & 12.5 & 12.2 & 11.1 & 4.1 & 16.3 & 18.2 & 15.6 & 16.7 & 15.0 & 4.8 \\
\hline No response & 84.4 & 75.6 & 66.7 & 73.5 & 69.8 & 81.8 & 71.1 & 50.0 & 55.0 & 57.1 \\
\hline Total respondents who grow/handle each crop & 87 & 87 & 140 & 87 & 104 & 55 & 89 & 54 & 96 & 156 \\
\hline
\end{tabular}

${ }^{\mathrm{z} O f}$ the 31 species, statice (Stat.), stock, sunflower (Sunf.), sweet pea (S. pea), sweet william (S. will.), tuberose (Tuber.), tulip, viburnum (Vib.), yarrow (Yar.), and zinnia are included here (see Tables 8 and 9 for remaining species). The number listed is the percentage of respondents who reported the issue for each species. Some respondents reported multiple production issues for a species $(n=54-56$ depending on the cut flower species).

${ }^{\mathrm{y}}$ In case of zinnia, the disease issue was specified as zinnia meltdown.

Most of these respondents specifically said that the problem was the lack of cooler space. As was previously mentioned, there is often a short harvest window for this crop, leading to crowded storage spaces.

Vase life was a problem during the postharvest of dahlia (11.1\%). Cut dahlias have a short vase life, and proper handling and treatments are needed to maintain that vase life (Bergmann et al., 2019). However, pulsing cut dahlias in a solution containing both benzyladenine and gibberellic acid improved flower quality and prolonged vase life.

Weak stems were a problem during the postharvest of calla (14.3\%); as discussed previously, researchers have worked on this issue for other species but have yet to address it in calla (Davies et al., 2002; Zhao et al., 2012, 2013).

Customer COMPLAINTS. The most significant customer complaints, as reported by at least $10 \%$ of the respondents, were failure to open, lack of supply, pollen, shattering, smell, and vase life (Tables 14-16). Failure to open was a complaint reported by $15.4 \%$ of the respondents for dutch iris. As was previously mentioned, the respondents who work with dutch iris complained about flowers opening during transport. However, their customers reported that dutch iris flowers might not open after they receive the flowers. Failure to open after storage/transport has been previously recognized as a major postharvest problem for dutch iris; experimentally, treatments such as gibberellic acid and thidiazuron stimulate growth of the pedicel and ovary and lead to a more complete opening of the inflorescence (Macnish et al., 2010).

Lack of supply was a complaint reported by $10.3 \%$ of the respondents for purple coneflower. Granitz (2014) found that the demand for specialty cut flowers has increased, and Armitage and Laushman (2003) reported an increasing demand for locally produced cut flowers. Nevertheless, it is not as simple as increasing the supply to match the demand because supply and demand determine the price of a crop. This means that increasing the supply can decrease the price of the product, thereby negatively impacting the producer (Armitage and Laushman, 2003). 
Research Reports

Table 11. Respondents to a 2017 survey regarding North American specialty cut flower production and postharvest issues were asked to identify their storage and transport postharvest challenges with 31 crop species. $^{\mathrm{z}}$

Ammi Anem. B. fls. Calla Coc. Cosm. Dah. Delph. D. iris Glad. Hyd. Respondents reporting postharvest challenge (\%)

Bent/snapped necks

Botrytis

Color fading

Curvy stems

Damage

Dropping flowers

Ethylene

Flower opens

Hydration

Insects

Packaging

Petal browning

Shattering

Stem length

Storage

Temperature management

Vase life

Weak stems

None

No response

Total respondents who grow/handle each crop

(no.)
$1.4 \quad 1.0$

1.4

9.5

4.4

11.1

4.4

14.3

1.9

2.2

1.9

10.0

$\begin{array}{llll}1.4 & 1.5 & 1.0 & \\ 1.4 & & 1.0 & 2.2\end{array}$

15.4

11.3

${ }^{2}$ Of the 31 species, ammi, anemone (Anem.), blue flossflower (B. fls.), calla, cockscomb (Coc.), cosmos (Cosm.), dahlia (Dah.), delphinium (Delph.), dutch iris (D. iris), gladiolus (Glad.), and hydrangea (Hyd.) are included here (see Tables 12 and 13 for the remaining species). The number listed is the percentage of respondents who reported the issue for each species. Some respondents reported multiple production issues for a species $(\mathrm{n}=21-139$, depending on the cut flower species).

Table 12. Respondents to a 2017 survey regarding North American specialty cut flower production and postharvest issues were asked to identify their storage and transport postharvest challenges with 31 crop species. $^{\mathrm{z}}$

\begin{tabular}{|c|c|c|c|c|c|c|c|c|c|c|}
\hline & Lark. & Lily & Lis. & Marig. & Peony & Phlox & P. con. & Ran. & Rose & Snap. \\
\hline & \multicolumn{10}{|c|}{ Respondents reporting postharvest challenge (\%) } \\
\hline Bent/snapped necks & & 4.8 & 1.4 & & & & & & & \\
\hline Color fading & & & & & & & & & & 2.9 \\
\hline Curvy stems & & & & & & & & & & 7.1 \\
\hline Damage & 5.0 & 16.7 & 4.3 & & 1.3 & & & 1.9 & 8.3 & 2.9 \\
\hline Flower opens & & & & & 2.6 & & & & & \\
\hline Hydration & & & & & & & & & & 1.4 \\
\hline Insects & & & & & & & & & & \\
\hline Packaging & & 2.4 & & & & & & & & \\
\hline Petal browning & & & & & 1.3 & & & 1.9 & & \\
\hline Vase life & & & & & 2.6 & & 3.5 & & 4.2 & 1.4 \\
\hline Weak stems & & 2.4 & 1.4 & 9.8 & & & & & & \\
\hline None & 13.3 & 4.8 & 10.0 & 9.8 & 9.0 & 12.5 & 20.7 & 9.6 & 4.2 & 11.4 \\
\hline No response & 68.3 & 64.3 & 80.0 & 80.5 & 59.0 & 75.0 & 72.4 & 84.6 & 83.3 & 67.1 \\
\hline Total respondents who grow/handle each crop & 90 & 69 & 120 & 77 & 141 & 62 & 51 & 84 & 38 & 140 \\
\hline
\end{tabular}

${ }^{\mathrm{z}}$ Of the 31 species, larkspur (Lark.), lily, lisianthus (Lis.), marigold (Marig.), peony, phlox, purple coneflower (P. con.), ranunculus (Ran.), rose, and snapdragon (Snap.) are included here (see Tables 11 and 13 for the remaining species). The number listed is the percentage of respondents who reported the issue for each species. Some respondents reported multiple production issues for a species $(\mathrm{n}=38-141$, depending on the cut flower species). 
Table 13. Respondents to a 2017 survey regarding North American specialty cut flower production and postharvest issues were asked to identify their storage and transport postharvest challenges with 31 crop species. ${ }^{2}$

\begin{tabular}{|c|c|c|c|c|c|c|c|c|c|c|}
\hline & Stat. & Stock & Sunf. & S. pea & S. will. & Tuber. & Tulip & Vib. & Yar. & Zinnia \\
\hline & \multicolumn{10}{|c|}{ Respondents reporting postharvest challenge (\%) } \\
\hline Bent/snapped necks & & & 1.6 & & & & & & & 7.1 \\
\hline Botrytis & & & & 2.0 & & & 4.4 & & & \\
\hline \multicolumn{11}{|l|}{ Color fading } \\
\hline Curvy stems & & & & & & & & & & 1.2 \\
\hline Damage & & 4.9 & 1.6 & 2.0 & & & & & & 4.8 \\
\hline \multicolumn{11}{|l|}{ Dropping flowers } \\
\hline \multicolumn{11}{|l|}{ Ethylene } \\
\hline Flower opens & & & & & & 4.6 & 2.2 & & & \\
\hline Hydration & & 2.4 & 4.8 & & 2.3 & & & 16.7 & 5.0 & 2.4 \\
\hline \multicolumn{11}{|l|}{ Insects } \\
\hline Packaging & & & 1.6 & 6.1 & & & & & & 2.4 \\
\hline Petal browning & & & & & & & & & & 1.2 \\
\hline Shattering & & & 4.8 & & & & & 5.6 & & \\
\hline \multicolumn{11}{|l|}{ Stem length } \\
\hline \multicolumn{11}{|l|}{ Storage } \\
\hline Temperature management & & & 3.2 & & & & 4.4 & 5.6 & 2.5 & 8.3 \\
\hline Vase life & & & & 4.1 & & & & & & 8.3 \\
\hline Weak stems & & & & 2.0 & & & & & & \\
\hline None & 15.6 & 17.1 & 11.1 & 6.1 & 14.0 & 13.6 & 15.6 & 22.2 & 22.5 & 8.3 \\
\hline No response & 84.4 & 75.6 & 71.4 & 77.6 & 83.7 & 81.8 & 73.3 & 55.6 & 70.0 & 61.9 \\
\hline Total respondents (no.) & 32 & 41 & 63 & 49 & 43 & 22 & 45 & 18 & 40 & 84 \\
\hline Total respondents who grow/handle each & 87 & 87 & 140 & 87 & 104 & 55 & 89 & 54 & 96 & 156 \\
\hline
\end{tabular}

${ }^{\mathrm{z}}$ Of the 31 species, statice (Stat.), stock, sunflower (Sunf.), sweet pea (S. pea), sweet william (S. will.), tuberose (Tuber.), tulip, viburnum (Vib.), yarrow (Yar.), and zinnia are included here (see Tables 11 and 12 for the remaining species). The number listed is the percentage of respondents who reported the issue for each species. Some respondents reported multiple production issues for a species $(n=54-156$, depending on the cut flower species).

Pollen was a complaint reported by $11.9 \%$ of the respondents for lily. Lily is one of the most important cut flowers, but it has reddish-brown pollen that can stain clothes and is poisonous to cats (Knight, 2001). Therefore, efforts have been made to produce pollenless lilies (Yamagishi, 2003). Currently, many growers manually remove the stamens to prevent pollen-related problems (Hamrick, 2003 ).

Shattering was a complaint for delphinium (13.3\%) and phlox (21.9\%). Smell was a complaint reported by $24.4 \%$ of the respondents for marigold. Marigold has a characteristic smell that is most pronounced during harvest and processing, and it tends to be disliked by producers and postharvest handlers (Dole et al., 2017a). The odor primarily comes from the foliage, not the flower; therefore, removing the leaves for the final consumer helps alleviate this effect (Reilly, 1983). Vase life was a complaint for cosmos (11.6\%), dahlia $(26.3 \%)$, dutch iris $(23.1 \%)$, rose $(16.7 \%)$, sweet pea $(16.3 \%)$, and zinnia $(20.2 \%)$. Respondents reported similar concerns for these species, as previously discussed.

\section{Conclusions}

The five most commonly grown or handled specialty cut flowers are zinnia, peony, snapdragon, sunflower, and dahlia. Breeders and other researchers can focus on the most important issues for these crops, such as powdery mildew and vase life for zinnia; botrytis, timing, weeds, temperature management, and storage for peony; aphids and rust for snapdragon; animals and timing for sunflower; and insects and vase life for dahlia.

The major overall production problems were insect management, followed by crop timing and disease management. Among the speciesspecific problems, aphids, beetles, and thrips were specifically mentioned for six cut flower species, and powdery mildew, root rot, and soft rot were specifically mentioned for four species. Short stem length and timing (specifically controlling flowering time and harvesting at the correct stage) were major concerns for eight species and animal issues were important for five species.
The main overall postharvest problems were temperature management, hydration, and flower food management. The major postharvest problems at the farm were hydration, which was significant for five species, vase life for three species, and shattering, stripping foliage/thorns, temperature management, timing, weak stems, and zinnia meltdown, each of which was significant for one species. The major postharvest problems during storage and transportation were damage and hydration for three species and flower opening, shattering, temperature management, vase life, and weak stems, each of which was significant for one species. The most important customer complaints were vase life for six species, shattering for two species, and failure to open, lack of supply, pollen, and smell for one species each.

The results of this survey can be used by researchers to focus on issues and the crops most in need of improvements. Improved production and postharvest handling will support the continued growth of the cut flower industry in North America. 
Table 14. Respondents to a 2017 survey regarding North American specialty cut flower production and postharvest issues were asked to identify their customer complaints for 31 crop species. ${ }^{\mathrm{z}}$

Ammi Anem. B. fls. Calla Coc. Cosm. Dah. Delph. D. iris Glad. Hyd. Respondents reporting customer complaint (\%)

Botrytis

Color range

Cost

Damage

Disease

Fail to open

Field production

Fragile

Head size (big)

Head size (small)

Hydration

Insects

Lack of demand

Lack of supply

Looks like weed

Messy

Neck damage

Not popular/dislike it

Opens too fast/too much

Petal browning

Pollen

Shattering

Slow opening

Smell

Stem length

Timing

Transportation

Thrips

Vase life

Weak flower/stems

Zinnia meltdown

None

No response

Total respondents who grow/handle each crop

$\begin{array}{ccc}\text { Respondents reportir } & 4.8 \quad 1.4\end{array}$

$\begin{array}{lll}4.8 & 1.5 & 1.0 \\ 9.2 & & 1.0\end{array}$

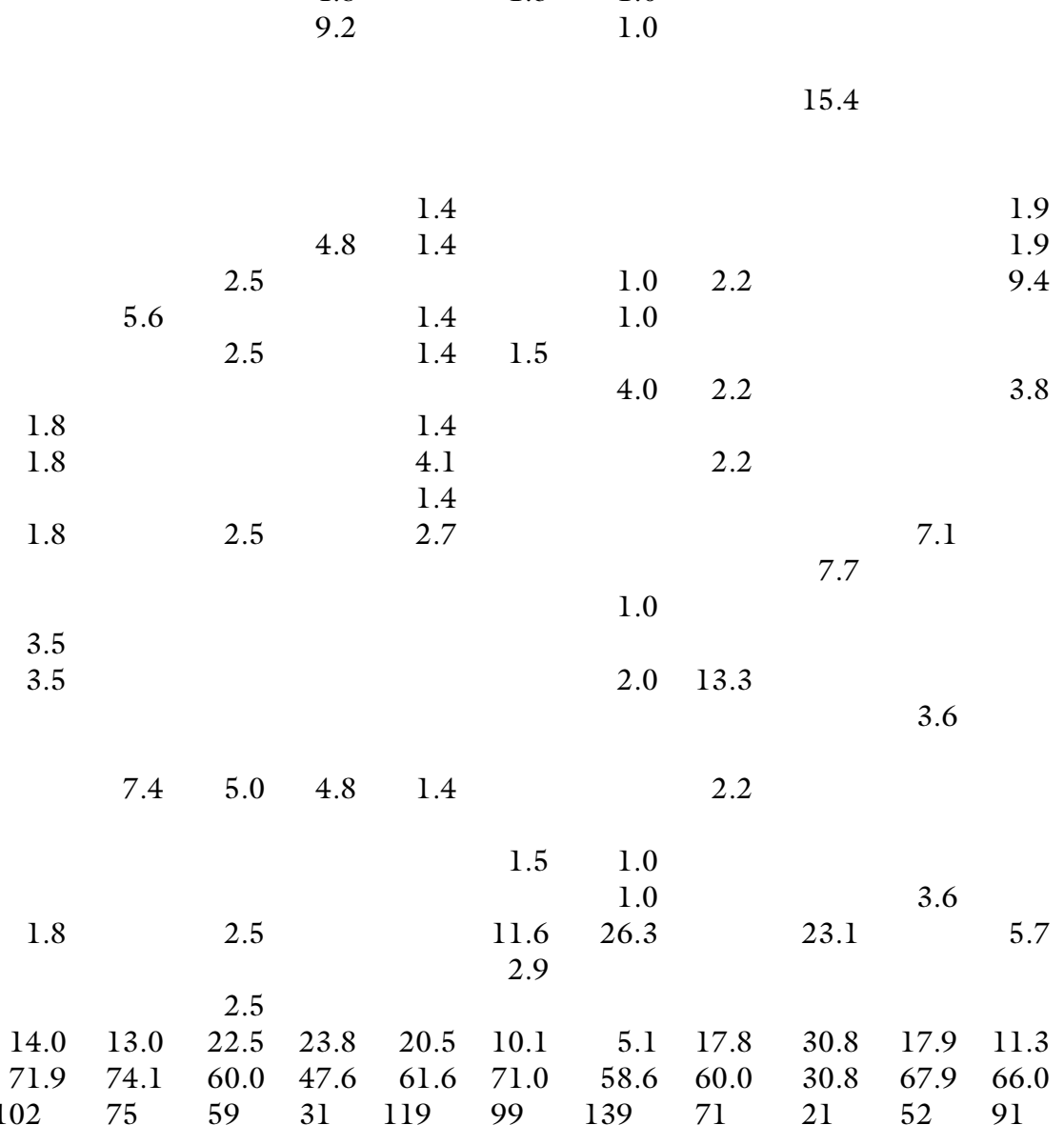

(no.)

${ }^{\mathrm{z}}$ Of the 31 species, ammi, anemone (Anem.), blue flossflower (B. fls.), calla, cockscomb (Coc.), cosmos (Cosm.), dahlia (Dah.), delphinium (Delph.), dutch iris (D. iris), gladiolus (Glad.), and hydrangea (Hyd.) are included here (see Tables 15 and 16 for remaining species). The number listed is the percentage of respondents who reported the issue for each species. Some respondents reported multiple production issues for a species ( $\mathrm{n}=21-139$, depending on the cut flower species).

\section{Literature cited}

Abbey, M. 2015. Paeonia ssp. production and future developments. 31 Mar. 2019. <https://conservancy.umn.edu/ handle/11299/175839>.

Ahmad, I., J.M. Dole, A.S. Carlson, and F.A. Blazich. 2013. Water quality effects on postharvest performance of cut calla, hydrangea, and snapdragon. Scientia Hort. $153: 26-33$.

Armitage, A.M. and J.M. Laushman. 2003. Specialty cut flowers: The production of annuals, perennials, bulbs, and woody plants for fresh and dried cut flowers. Timber Press, Portland, OR.

Association of Floral Importers of Florida. 2009. Cut flower minimum guidelines and standards. 31 Mar. 2019. <https:// www.afifnet.org/sites/default/files/ PDF/cut_flowers_minimum_guidelines_ standards.pdf $>$.

Bergmann, B.A., I. Ahmad, and J.M. Dole. 2019. Benzyladenine and gibberellic acid pulses improve flower quality and extend vase life of cut dahlias. Can. J. Plant Sci. 99:97-101.

Bogash, S., T. Ford, L. Kime, and J. Harper. 2012. Alternative agriculture: Cut flower production. Pennsylvania State Univ. Ext. EE0047.

Bout, A., R. Boll, L. Mailleret, and C. Poncet. 2010. Realistic global scouting for pests and diseases on cut rose crops. J. Econ. Entomol. 103:2242-2248.
Byczynski, L. 2008. The flower farmer: An organic grower's guide to raising and selling cut flowers. Chelsea Green Publ., White River Junction, VT.

Davies, L.J., I.R. Brooking, J.L. Catley, and E.A. Halligan. 2002. Effects of day/ night temperature differential and irradiance on the flower stem quality of Sandersonia aurantiaca. Scientia Hort. 95:85-98.

Dole, J.M. and H.F. Wilkins. 2005. Floriculture: Principles and species. Pearson Prentice Hall, Upper Saddle River, NJ.

Dole, J.M. and M.A. Schnelle. 1993. A comparison of attitudes and practices among sectors of the Oklahoma floriculture industry. HortTechnology 3: 343-347. 
Table 15. Respondents to a 2017 survey regarding North American specialty cut flower production and postharvest issues were asked to identify their customer complaints for 31 crop species. ${ }^{2}$

\begin{tabular}{|c|c|c|c|c|c|c|c|c|c|c|}
\hline & Lark. & Lily & Lis. & Marig. & Peony & Phlox & P. con. & Ran. & Rose & Snap. \\
\hline & \multicolumn{10}{|c|}{ Respondents reporting customer complaint (\%) } \\
\hline Botrytis & & 2.4 & & & 3.9 & & & & & \\
\hline Color range & & & & 4.9 & & & & & & \\
\hline Cost & 1.7 & 2.4 & 2.9 & & 7.7 & & & & 8.3 & \\
\hline Damage & & 7.1 & & & & & & & & \\
\hline Disease & & & & & & & & & & \\
\hline Fail to open & & & 1.4 & & 2.6 & & & & & \\
\hline Field production & & & & & & & & & & \\
\hline Fragile & 1.7 & 2.4 & & & & 3.1 & & & & \\
\hline Head size (big) & & & & & & & & & & \\
\hline Head size (small) & 1.7 & & & & 1.3 & & & 1.9 & & \\
\hline Hydration & & & & & 2.6 & & & & & 1.4 \\
\hline Insects & & & & & & & & & & \\
\hline Lack of demand & & 2.4 & 2.9 & 7.3 & & & 6.9 & & & 1.4 \\
\hline Lack of supply & & & 4.3 & & 2.6 & & 10.3 & 1.9 & 8.3 & \\
\hline Looks like weed & & & & & & & 3.4 & & & \\
\hline Messy & & & & & & & & & & \\
\hline Neck damage & & & & & & & & & & \\
\hline Not popular/dislike it & & & & & & & & & & \\
\hline Opens too fast/too much & 1.7 & 2.4 & & & 1.3 & & & & & \\
\hline Petal browning & & & & & & & & & & \\
\hline Pollen & & 11.9 & & & & & & & & \\
\hline Shattering & 5.0 & 2.4 & & & & 21.9 & 3.4 & & 4.2 & 1.4 \\
\hline Slow opening & & & & & & & & & 4.2 & \\
\hline Smell & & 4.8 & & 24.4 & & & & & & \\
\hline Stem length & 3.3 & & 1.4 & & & & & 1.9 & & 2.9 \\
\hline Timing & & 2.4 & & & & & & & & \\
\hline Transportation & & & & & 1.3 & & & & & \\
\hline Thrips & & & & & & & & & & \\
\hline Vase life & & & & & 2.6 & & & & 16.7 & \\
\hline Weak flowers/stems & & & & & & & & & & 1.4 \\
\hline Zinnia meltdown & & & & & & & & & & \\
\hline None & 18.3 & 9.5 & 11.4 & 9.8 & 9.0 & 12.5 & 13.8 & 9.6 & 4.2 & 12.9 \\
\hline No response & 66.7 & 50.0 & 75.7 & 53.7 & 65.4 & 62.5 & 62.1 & 84.6 & 58.3 & 78.6 \\
\hline $\begin{array}{l}\text { Total respondents who grow/handle each crop } \\
\text { (no.) }\end{array}$ & 90 & 69 & 120 & 77 & 141 & 62 & 51 & 84 & 38 & 140 \\
\hline
\end{tabular}

${ }^{\mathrm{Z}}$ Of the 31 species, larkspur (Lark.), lily, lisianthus (Lis.), marigold (Marig.), peony, phlox, purple coneflower (P. con.), ranunculus (Ran.), rose, and snapdragon (Snap.) are included here (see Tables 14 and 16 for the remaining species). The number listed is the percentage of respondents who reported the indicated issue for each species. Some respondents reported multiple production issues for a species $(n=38-141$, depending on cut flower species).

Dole, J.M. and M.A. Schnelle. 2004. The care and handling of cut flowers. Oklahoma State Univ. Ext. Facts No. 6426. 31 Mar. 2019. <http://pods.dasnr.okstate. edu/docushare / d sweb/Get / Document-1115/HLA-6426web.pdf>.

Dole, J.M., I.F. McCall, and J.M. Laushman. 2017a. 2017 ASCFG seed trial report. Cut Flower Qrtly. 30:22.

Dole, J.M., R. Stamps, A. Carlson, I. Ahmad, L. Greer, and J. Laushman. $2017 \mathrm{~b}$. Postharvest handling of cut flowers and greens, A practical guide for commercial growers, wholesalers and retailers. Assn. Specialty Cut Flower Growers, Oberlin, $\mathrm{OH}$.

Eason, J., T. Pinkney, J. Heyes, D. Brash, and B. Bycroft. 2002. Effect of storage temperature and harvest bud maturity on bud opening and vase life of Paeonia lactiflora cultivars. N. Z. J. Crop Hort. Sci. 30:61-67.

Flowers Canada Growers. 1996. Recommended grades and standards for fresh cut flowers. 31 Mar. 2019. <https://www. flowerscanadagrowers.com/uploads / $2016 / 11 /$ grades $\% 20 \& \% 20$ standards $\%$ 20 for $\% 20$ fresh $\% 20$ cut $\% 20$ flowers.pdf>.

Granitz, H.M. 2014. Improving the North Carolina cut flower industry: A production and marketing survey, field and postharvest cut flower variety evaluations, and preemergence herbicide trials on unlabeled cut flower crops. MS Thesis, North Carolina State Univ., Raleigh.

Halevy, B. and S. Mayak. 1979. Senescence and postharvest physiology of cut flowers, Part 1. Hort. Rev. 1:204-236.
Hamrick, D. 2003. Ball redbook, Crop production. Vol. 2. Ball Publ., Batavia, IL.

Harbaugh, B.K. and R.J. McGovern. 2000. Susceptibility of forty-six Lisianthus cultivars to fusarium and stem rot. HortTechnology 10:816-819.

Hoshi, H., Y. Sato, S. Kagiwada, and H. Horie. 2013. First report of powdery mildew on zinnia, blue torenia, dahurian patrinia and scoparia caused by genus Euodium in Japan. J. Gen. Plant Pathol. 79:89-95.

Kamenetsky, R. and J. Dole. 2012. Herbaceous peony (Paeonia): Genetics, physiology and cut flower production. Floric. Ornam. Biotechnol. 6:62-77.

Karl, T.R. and W.J. Koss. 1984. Regional and national monthly, seasonal, and annual temperature weighted by area, 
Table 16. Respondents to a 2017 survey regarding North American specialty cut flower production and postharvest issues were asked to identify their customer complaints for 31 crop species. ${ }^{2}$

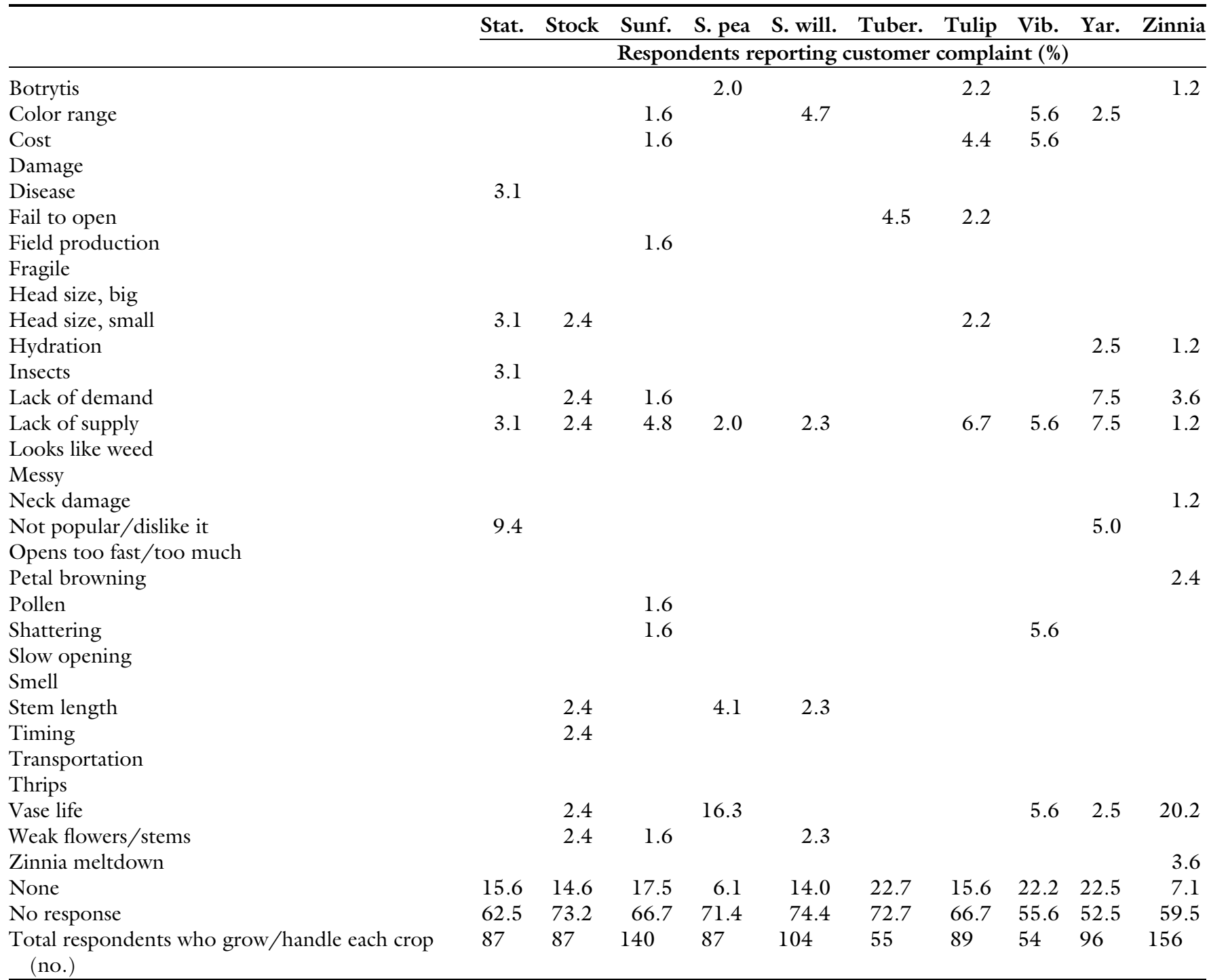

${ }^{\mathrm{z}}$ Of the 31 species, statice (Stat.), stock, sunflower (Sunf.), sweet pea (S. pea), sweet william (S. will.), tuberose (Tuber.), tulip, viburnum (Vib.), yarrow (Yar.), and zinnia are included here (see Tables 14 and 15 for the remaining species). The number listed is the percentage of respondents who reported the indicated issue for each species. Some respondents reported multiple production issues for a species $(\mathrm{n}=54-156$, depending on the cut flower species).

1895-1983. 31 Mar. 2019. <https:// www.ncdc.noaa.gov/monitoringreferences/maps/us-climate-regions.php>.

Knight, T. 2001. Guide to poisonous plants. 31 Mar. 2019. <https://csuvth. colostate.edu/poisonous_plants/Plants/ Details/76>.

Kuehny, J.S. 2000. Calla history and culture. Hort Technology 10:267-274.

Macnish, A.J., C. Jiang, and M.S. Reid. 2010. Treatment with thidiazuron improves opening and vase life of iris flowers. Postharvest Biol. Technol. 56: 77-84.

Moore, K. and L.K. Bradley. 2018. North Carolina Extension gardener handbook, North Carolina State Ext., North Carolina State Univ., Raleigh.
Mori, Y. 2006. Effects of high temperature treatment on seed-germination of rocket larkspur (Consolida ambigua L.). Engeigaku Kenkyuu 5:453-457.

Mouden, S., K.F. Sarmiento, P.G. Klinkhamer, and K.A. Leiss. 2017. Integrated pest management in western flower thrips: Past present and future. Pest Mgt. Sci. 73:813-822.

Muthukumar, A., G. Karthikeyan, and K. Prabakar. 2006. Management of tuber rot (Fusarium oxysporum) of tuberose (Polianthes tuberosa L.). Madras Agr. J. 93(1-6):132-134.

Nelson, P.V. 1998. Greenhouse operation and management. Prentice Hall, Upper Saddle River, NJ.

Nowak, J. 1990. Postharvest handling and storage of cut flowers, florist greens, and potted plants. Timber Press, Portland, OR.

Patterson, S.E. and A.B. Bleecker. 2004. Ethylene-dependent and independent processes associated with floral organ abscission in arabidopsis. Plant Physiol. 134:194-203.

Reid, M.S. 2006. Air transport of cut flowers. 31 Mar. 2019. <https://ucanr. edu/datastoreFiles/234-1373.pdf>.

Reilly, A. (ed.). 1983. Marigold: Care tips for the florist. New York State Flower Ind. Bul. 153:6.

Saha, T. and M.R. Khan. 2016. Evaluation of bioformulations for management of root knot nematode (Meloidogyne incognita) infecting tuberose. Pak. J. Zool. 48:651-656. 
Siddiqui, M. 2015. Postharvest management of fresh cut flowers, p. 347-400. In: V. Mishra and S.K. Dwifedi (eds.). Postharvest biology and technology of horticultural crops. Apple Academic Press, New York, NY.

Spooner, D.M., D.P. Stimart, and T.H. Boyle. 1991. Zinnia marylandica (Asteraceae: Heliantheae), a new disease resistant ornamental hybrid. Brittonia 43:7-10.

Sun, D. and T. Brosnan. 1999. Extension of the vase life of cut daffodil flowers by rapid vacuum cooling. Intl. J. Refrig. 22:472-478.

Tanase, K., K. Tokuhiro, M. Amano, and K. Ichimura. 2009. Ethylene sensitivity and changes in ethylene production during senescence in long-lived Delphinium flowers without sepal abscission. Postharvest Biol. Technol. 52:310-312.
Torra, J., A. Royo-Esnal, J. Recasens, and P. Westerman. 2015. Germination ecology of five arable Ranunculaceae species. Weed Res. 55:503-513.

van Doorn, W.G. 2004. Is petal senescence due to sugar starvation? Plant Physiol. 134:35-42.

van Doorn, W.G. and C. Kamdee. 2014. Flower opening and closure: An update. J. Expt. Bot. 65:5749-5757.

van Doorn, W.G. and U.V. Meeteren. 2003. Flower opening and closure: A review. J. Expt. Bot. 54:1801-1812.

Yamagishi, M. 2003. A genetic model for a pollenless trait in Asiatic hybrid lily and its utilization for breeding. Scientia Hort. 98:293-297.
Zhao, D., Z. Hao, J. Tao, and C. Han. 2013. Silicon application enhances the mechanical strength of inflorescence stem in herbaceous peony (Paeonia lactiflora Pall.). Scientia Hort. 151:165-172.

Zhao, D., C. Han, J. Tao, J. Wang, Z. Hao, Q. Geng, and B. Du. 2012. Effects of inflorescence stem structure and cell wall components on the mechanical strength of inflorescence stem in herbaceous peony. Intl. J. Mol. Sci. 13:4993-5009.

Zhu, W., F. Zhang, S. Chen, L. Xu, L. Wang, H. Wang, X. Qi, H. Li, and F. Chen. 2014. Intergeneric hybrids between Chrysanthemum morifolium 'Nannongxiaoli' and Artemisia vulgaris 'Variegata' show enhanced resistance against both aphids and Alternaria leaf spot. Euphytica 197:399-408. 